\title{
TERRAS QUILOMBOLAS: UM ABISMO ENTRE OS CERTIFICADOS E OS TÍTULOS
}

\section{ARTIGO ORIGINAL}

SANTOS, Cleidison Da Silva ${ }^{1}$

CARDOSO, Alessandra Lopes ${ }^{2}$

MARTINS, Arlon Francisco Carvalho ${ }^{3}$

MIRANDA, Igor De Sousa ${ }^{4}$

SANTOS, Cleidison Da Silva. Et al. Terras Quilombolas: Um abismo entre os certificados e os títulos. Revista Científica Multidisciplinar Núcleo do Conhecimento. Ano 04, Ed. 07, Vol. 11, pp. 121-147. Julho de 2019. ISSN: 2448-0959

\section{RESUMO}

O presente estudo é uma análise do quantitativo de comunidades quilombolas certificadas no Brasil entre 2004 a fevereiro de 2019. Para mais, revisa a relevância dos certificados e títulos das terras para estas comunidades, assim como, possíveis investimentos em políticas públicas. Portanto, questionamos: com o reconhecimento dos quilombolas, por que a entidade étnica sujeita à proteção estatal, sujeito de direito, e o aumento de certificados emitidos nas duas últimas décadas caminham pelo lado oposto da agenda de investimento do Estado? Sabemos que grande demanda de quilombos, já certificados, entre 2004 a 2019 implica na busca dos títulos de suas terras. Os dados obtidos neste estudo nos revelam que houve um aumento no número de comunidades certificas, em contrapartida uma redução no investimento por parte

\footnotetext{
${ }^{1}$ Doutorando em Educação: Universidade Nacional de Rosario - UNR.

2 Doutorando em educação: Universidade Nacional de Rosario - UNR.

${ }^{3}$ Doutorado em Linguística pela Universidade Federal do Ceará.

${ }^{4}$ Mestre em Química - UFPA.
} 
do Estado. Apesar dos recursos de 54,2 milhões em 2010 e 50 milhões em 2012, apenas 174 comunidades receberam os títulos de suas terras. Os dados obtidos mostram que o número crescente de comunidades certificadas não é contemplado com os repasses de recursos para titular as terras. Os repasses do governo federal, o processo de certificação das comunidades e a presunção da obtenção de títulos, estão em direções opostas.

Palavras chave: Identidade, Quilombola, território.

\section{INTRODUÇÃO}

A partir da Constituição Federal de 1988, as políticas públicas no Brasil ganharam novos horizontes. Durante anos, as lutas dos negros para garantir seus direitos foram intensas e desgastantes. Desde a Lei do Ventre livre em 1871, ao contrário do que pensamos, os negros livres passaram a enfrentar constantes lutas para garantir igualdades sociais. Os quilombos, no século XIX, passaram não receber apenas negros fugitivos, os espaços tornaram lugares de amparo a negros livres que buscavam aceitação. A liberdade neste aspecto trouxe a desorientação social de milhares de ex-escravizados que não sabiam para onde ir. Neste cenário, novas comunidades quilombolas formaram em todos os estados, com exceção de Roraima e Acre. Desde então, há inserções de políticas públicas.

A materialidade do art. 68 da Constituição de 1988 trouxe a garantia territorial para as comunidades quilombolas, "Aos remanescentes das comunidades dos quilombos que estejam ocupando suas terras é reconhecida a propriedade definitiva, devendo o Estado emitir lhes os títulos respectivos". A partir do reconhecimento territorial, material e imaterial da cultura negra no Brasil, as comunidades passaram a reivindicar seus direitos. As terras são de grande relevância para estes povos. Para além de sua subsistência, a terra é o elo que liga presente e passado, é o que define o ser quilombo.

As comunidades espalhadas no Brasil passam a ganhar visibilidade com os pedidos de reconhecimento garantido em lei. Durante duas décadas eclodiram vários pedidos 
de certificação. Os comunitários passaram a compreender que as políticas públicas específicas ao desenvolvimento social quilombola só tornam tangível às comunidades, a priori, com a certificação.

Conforme os dados obtidos no INCRA, o orçamento para titulação de terras quilombolas, entre 2010 a 2018, o caiu 97\%. Para 2018, foram previstos menos de $\mathrm{R} \$ 1$ milhão para a titulação dos mais de 1,7 mil processos abertos. Encaldado destes dados, propomos analisar o quantitativo de comunidades quilombolas certificadas no período de 2004 a fevereiro de 2019. Os resultados são vistos como uma demanda real, a implementação, de novas políticas públicas frente os baixos repasses do Governo Federal, entre 2010 a 2019, para manutenção e preservação da memoria afro brasileira nestas comunidades.

Portarias, decretos e leis; direcionadas aos quilombolas, devem estar ligadas ao espaço e tempo concernente a preservação da memoria, identidade e cultura dos quilombos. A certificação destas comunidades, de acordo com a Fundação Cultural Palmares, responsável pelo processo: "é o primeiro passo para a demarcação e titulação de terras pelo Instituto Nacional de Colonização e Reforma Agrária - INCRA, como reconhecimento de que a comunidade existe baseada em sua história, costumes e, principalmente, sua cultura". Os primeiros certificados, conforme dados obtidos da Fundação Palmares, foram emitidos em 2004. Deste então, temos 3.271 comunidades certificadas no país. Deste número, segundo os dados do INCRA e da própria fundação, temos apenas 174 comunidades tituladas. É imensurável a relevância dos certificados, assim, como os títulos para estas comunidades. Há um número ainda incalculável de comunidades em território nacional que não tem seus certificados.

Para o Brasil é uma perca que ultrapassa os limites materiais. Sem os certificados as políticas públicas específicas para os quilombolas, conquistadas ao longo de uma história marcada por lutas, não chegam a estas comunidades. Este é um dos problemas enfrentados por comunidades ainda "invisíveis" no Brasil. As comunidades que adquirem seus certificados passam a ser "visível", traçam lutas em busca de direitos, muitas vezes, suprimidos pelo poder público. A grande demanda de 
quilombos, já certificados, entre 2004 a 2019 implica na busca dos títulos de suas terras. Os dados obtidos neste estudo nos revelam que houve um aumento no número de comunidades certificas, em contrapartida uma redução no investimento por parte do Estado. De acordo com o INCRA, de 54,2 milhões em 2010, os repasses do governo Federal caíram para 956 mil em 2018, para demarcação e titulação de terras quilombolas. A assertiva responde o questionamento: com o reconhecimento dos quilombolas por que a entidade étnica sujeita à proteção estatal, sujeito de direito, e o aumento de certificados emitidos nas duas últimas décadas caminham pelo lado oposto da agenda de investimento do Estado? Estas comunidades estão geralmente distantes da cidade, apresentam traços de fragilidade e precariedade econômicas. Vivem do artesanato e da agricultura de subsistência familiar e pesca.

Mais tarde, o decreto ํo 4887, de 20 de novembro de 2003 vem estabelecer os processos administrativos para o reconhecimento destas comunidades. Sabemos que todas as políticas públicas quilombolas são para comunidades já certificadas. Dai a relevância dos certificados e títulos obtidos ao longo das duas décadas. Estes certificados acabam influenciando de forma econômica a vida comunitária.

Para demostrar a quantidade de certificados emitidos e possíveis impactos, políticas públicas e suas contingências. A análise consiste na amostra de quantidade de certificados emitidos, no período de 2004 a fevereiro de 2019;construímos gráficos que apontam o reconhecimento destas comunidades no período supracitado. Percebemos que os certificados emitidos variam de ano para ano e de estado para estado. Esta variação é regida pelos momentos políticos. Montamos uma tabela dos repasses do Governo Federal para o INCRA; comparamos os repasses com o número de comunidades tituladas. Por fim, o estudo mostra o risco decadente, derivante, da falta de visibilidade e omissão do governo podem trazer a memória cultural brasileira.

\section{CONSTITUIÇÃO FEDERAL DE 1988: A SUPERAÇÃO DE PARADIGMAS}

Ao longo da história, os negros no Brasil travaram incessantes lutas para conquista e efetivar os seus direitos suprimidos desde o Brasil colonial. As políticas públicas que 
remete ao período lei do Ventre Livre em 1871 tentam reparar as mazelas provocadas pelo processo de escravidão no país. Os negros escravizados ao buscarem refugiam nos quilombos, "homens e mulheres que se recusavam viver sob o regime da escravidão e desenvolviam ações de rebeldia e de luta contra esse sistema" (MUNANGA \& GOMES, 2006 p. 72); desde então, lutam por sua territorialidade, por uma educação de qualidade por meio da liberdade, preservação de suas memorias e identidades.

A Constituição Federal de 1988 torna se a base fundamental para garantia e preservação dos direitos de negros e seus descendentes escravizados no Brasil. Estas nova inserção tenta mudar elementos essencial que compõem a figura do quilombola brasileiro, que até então, não era reconhecido. O reconhecimento destes elementos: identidade, cultura, território e memoria negra vêm ser um imperativo para fundamentar as políticas públicos quilombolas.

\section{TERRITÓRIO E IDENTIDADE}

\subsection{REALIDADE E DESAFIOS DAS COMUNIDADES QUILOMBOLAS}

Não há política públicas específicas para comunidades quilombolas se não houver o reconhecimento de suas terras. O primeiro passo e um longo desavio das comunidades é a busca pela certificação de suas terras conforme previsto em lei. A titulação das terras previsto no art. 68 da Constituição Federal torna se imprescindível para a implantação de outras políticas públicas. A área certificada é submetida a um laudo antropológico, base pra o Relatório Técnico de Identificação e Delimitação (RTID). Sendo titula, segundo Silva (2012, p.56), "passa a ser concebida como uma propriedade coletiva, inalienável, impenhorável e imprescritível". O reconhecimento passa a alterar as condições de vida nas comunidades. Ao ponto que entendemos que as demais políticas, somente tornam se tangível para os comunitários após o reconhecimento. Em termos de relevância do território para os quilombolas, fica evidente que cada território não diz respeito apenas à função ou ao ter, mas ao SER. Com relação a este principio, Haesbaert (1997, p.46) mostra que, "é espiritual e não material e esquece-lo é se sujeitar a não compreender a violência trágica de muitas 
lutas". O espaço quilombola é muito mais que um espaço físico, de fato, apresenta se como um espaço de identidade do grupo ou de pertencimento a este.

A notícia que assola as comunidades quilombos neste ano, 2019, publicada pelo site Carta maior (2019), é que "Os recursos previstos para os quilombolas foram reduzidos em quase $80 \%$ e a lentidão dos processos de regularização dos territórios é uma deficiência Estado". Em entrevista ao site Denildo Biko Rodrigues, da direção da Coordenação Nacional dos Movimentos Quilombolas (Conaq) revela que,

Para a temática quilombola foi um corte muito alto. Na regularização dos territórios quilombolas foi cortado $78 \%$ do pouco recurso que tinha. Isso é muito ruim, porque já não era suficiente para indenizar as áreas decretadas pela presidenta desde 2010. E você imagina com apenas $22 \%$ do que sobrou, não dá para fazer tudo.

O programa Brasil Quilombola foi lançado em 12 de março de 2004, o programa instituiu a Agenda Social Quilombola (decreto no 6261/2007) que agrupa ações voltadas às Comunidades Remanescentes de Quilombos em várias áreas. Em tese, os eixos descritos abaixo visão melhorar a qualidade de vida das famílias. Para isso, institui: Eixo 1 - acesso à terra; Eixo 2 - infraestrutura e qualidade de vida; Eixo 3inclusão produtiva e desenvolvimento local; Eixo 4 - direito e cidadania. No entanto, os relatos das comunidades por todo Brasil, ainda sofrem intangibilidade desta políticas. A maioria das comunidades está assentada nas zonas rurais, o acesso à água potável, a falta de isento o a produção agrícola familiar, o escoamento das poucas produções, a falta de moradias dignas. Para mais além, as comunidades que vivem nas proximidades dos grandes centro sofrem com as especulações imobiliárias. Podemos citar como exemplo comunidades como quilombo Silva, no Rio Grande do Sul e Sacopã, no Rio de Janeiro os avanços e crescimentos das cidades envolveram as. Os prédios luxuosos a sua volta são parte da realidade destes quilombos. Até então, os prédios envoltos não seria o problema. Errado, uma vez que sabemos que as grandes especulações imobiliárias acabam pressionando para a não titulação das terras, dificultando assim o acesso às demais políticas pública destas comunidades. 
A sobrevivência dos comunitários quilombolas, em geral, está ligada à produção agrícola familiar. Alguns quilombos na Amazônia têm como pratica a pesca e a coleta de castanha-do-pará. Segundo Silva (2012, p. 76), "Nos quilombolas de Oriximiná Pa, a castanha é um elemento da identidade étnica dos remanescentes. Delimitadora da fronteira étnica entre e os demais setores da população rural da região dedicadamente à agricultura e à pecuária". Distribuídos em nove territórios étnicos, as margens dos rios Trombetas e Erepecuru, Acapu e Cuminã, segundo Silva (2012, p.61) "por ocasião da exploração da borracha e dos cacoais (fibras vegetais) ainda no início do século XX se deslocavam para fundar quilombos". O número expressivo de comunidades nas regiões de Santarém, Alenquer, Óbidos. Monte Alegre e Oriximiná, todas as cidade do estado do Pará, não inibiu a presença de empresas de mineração, de recursos hidroelétricos e de exploração de madeira que devastam os recursos naturais de potencial econômico sustentável das comunidades.

Em 2013, o jornal o Globo denuncia as condições precárias das comunidades quilombolas do Tocantins. Com título "Quilombolas enfrentam dificuldades de acessar serviços públicos" o site traz a realidade das comunidades: de Santa Fé do Araguaia, Muricilândia e Aragominas do estado do Tocantins. A reportagem disposta no G1 (2019), é composta por entrevistas de moradores das referidas comunidades. Na fala da moradora, a aposentada Maria de Lourdes Mendes, de acordo com a entrevista, ela foi contemplada pelo programa social Minha Casa Minha Vida, para construção de casa própria, "O dinheiro veio, mas não fizeram as casas. Eu aposentei e agora estou tirando aos poucos para terminar a casa". A reportagem vai mais além quando a conversa amplia para outros moradores. O Sr. José Moreira, produtor rural relata que "para plantar a dificuldade é grande e na hora de colher não temos o comprador certo". Em entrevista, o defensor público Hudy Ribeiro fala que as dificuldades enfrentadas pelo remanescestes quilombolas já faz parte da pauta da defensoria publica e que "Já oficiamos diversos órgãos, especialmente os municipais cobrando melhorias em saúde e educação".

Todas as dificuldades apresentadas nas comunidades quilombolas do Tocantins, apenas é um retalho de todo um tecido manchado pela omissão do poder público. As 
políticas que são para a melhoria de vida destas pessoas acabam não chegando até elas. As lutas incessantes pela busca dos seus direitos ampliaram desde a década de 80 , outrora as demandas, há bastante tempo, tanto no setor agrícola quanto no de moradia ou educação cidadã, são ponto que infringe nas condições de permanecia e manutenção de culturas afro-brasileira.

\section{ANÁLISE DISCURSIVA}

\subsection{DISTRIBUIÇÕES DE COMUNIDADES QUILOMBOLAS CERTIFICADAS NO BRASIL}

Os dados apresentados abaixo abordam as Certidões expedidas às comunidades Remanescentes de Quilombos (CRQS) atualizadas até a portaria no 34/2019, publicada no dou de 18/02/2019. Não se sabe ao certo o número de comunidade quilombolas no território brasileiro, entre tituladas e não tituladas este número pode chegar mais cinco mil comunidades espalhadas em todo território nacional com exceção do estado de Roraima, Acre e o Distrito Federal. Os números que apresentaremos são referentes a cada estado, criamos gráficos que mostram a evolução da obtenção de certidões de cada estado no período e 2004 a fevereiro de 2019.

O processo de certificação das comunidades dos remanescentes quilombolas no Brasil, no período de 2004 a fevereiro de 2019, mostra as recentes conquistas e baixas frente a lutas seculares dos remanescentes pelos seus direitos. A portaria 34/2019 publicada em 18/02/2019 revela a soma de 3.271 comunidades certificadas. Logo, é imensurável a relevância das terras para os quilombolas, como já discutido em seções anteriores. A certificação emitida pela Fundação Palmares é o primeiro passo para a titulação das terras. Todos os processos de titulação só vieram após a Constituição Federal de 1988. O decreto ํㅜ 4887, de 20 de novembro de 2003, é que estabelece 0 processo administrativo para o reconhecimento destas comunidades. Estas áreas certificadas são submetidas a um laudo antropológico, base de um Relatório Técnico de identificação e de Delimitação (RTID). (Segundo o relatório de 2019 do INCRA 
(INSTITUTO NACIONAL DE COLONIZAÇÃO E REFORMA AGRÁRIA), titulou apenas 174 comunidades em todo território Brasileiro). Sem o título das terras, o devido reconhecimento do governo frente às comunidades, todas as política públicas conquistadas, desde então, não são tangíveis aos grupos comunitários. Daí a relevância do status de terras tituladas.

\section{Comunidades quilombolas do Rio Grande do Sul}

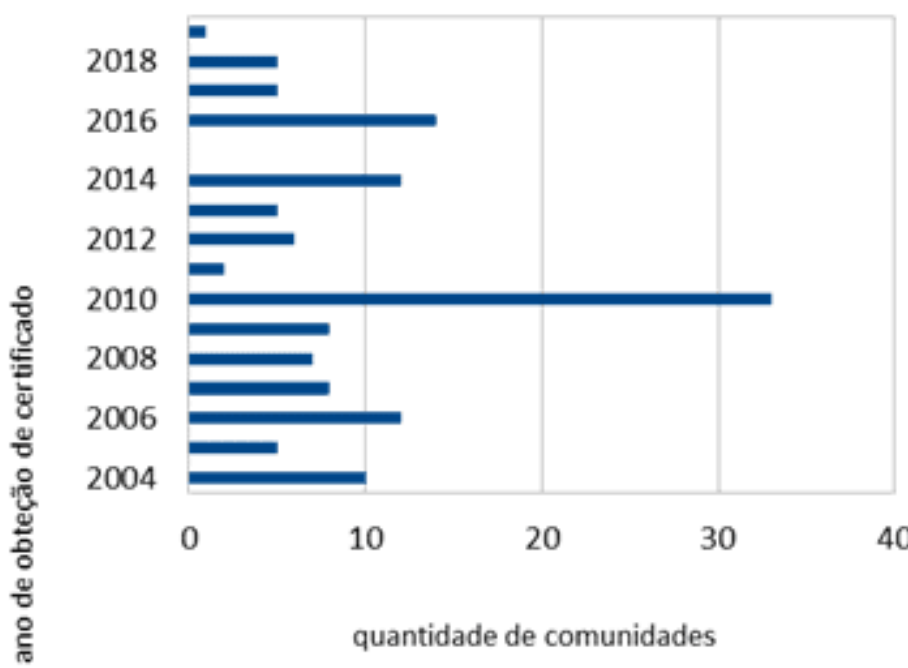

- Comuniades certificadas

Fonte: Fundação Palmares.

No estado do Rio Grande do Sul, entre comunidades denominadas urbanas e rurais o número de obtenção de certidões, no período 2004 ao primeiro semestre de 2019, conforme os dados publicados na portaria no 34/2019, publicada no DOU de 18/02/2019, são 133 comunidades. Entre 2004 a 2010, houve um crescimento expressivo nas concessões de certidões. Em 2010, foram certificadas 33 comunidades, este número corresponde a $24,81 \%$ do total de comunidades reconhecidas até então. De 2011 ao primeiro semestre de 2019, houve oscilações. Em 2011, apenas 02 (duas) comunidades receberam seus respectivos certificados. Números que representam um declínio com relação ao ano anterior. Em 2016, foram certificadas 14 comunidades, representando um $10.52 \%$ do total. Nos anos seguintes mais 10 (dez) comunidades. 


\section{Comunidades quilombolas de Santa Catarina}

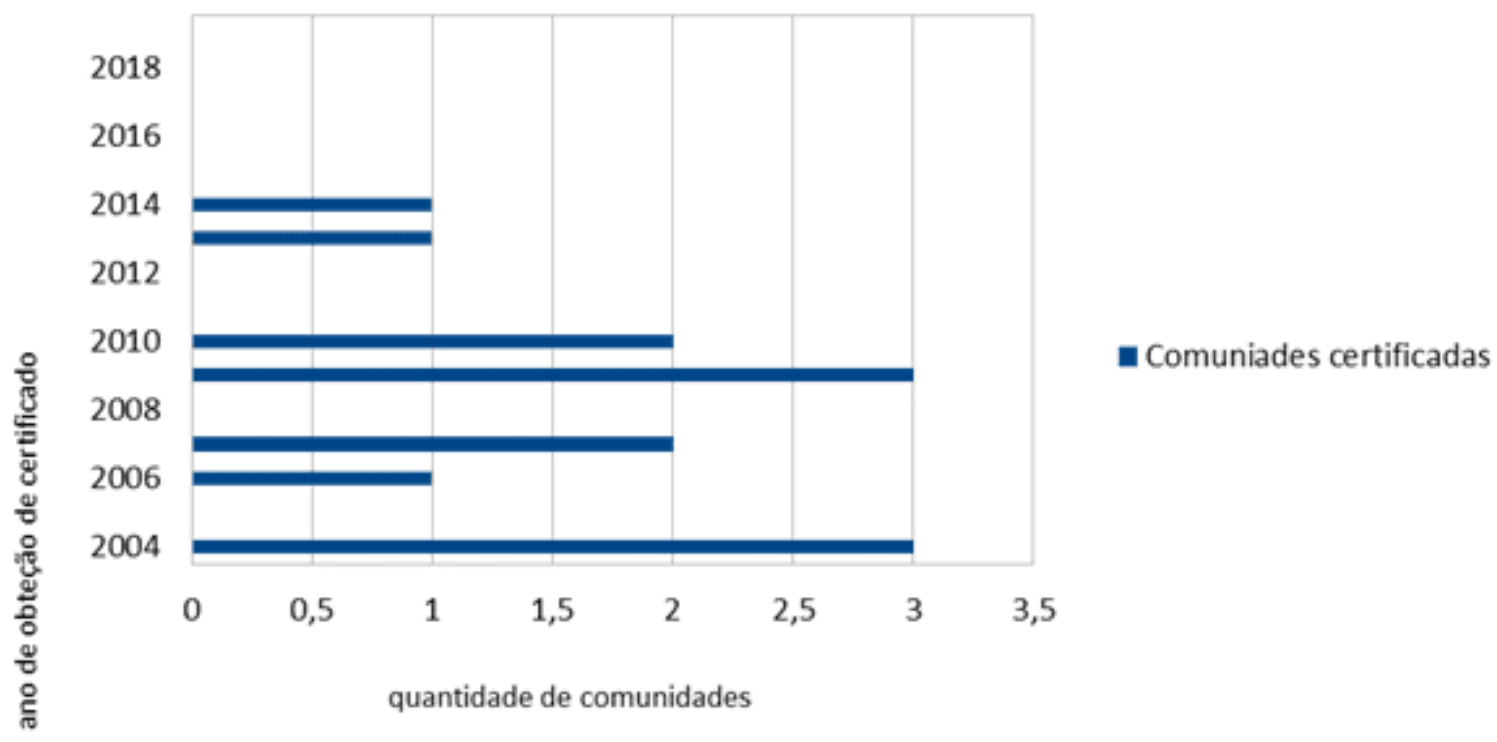

Fonte: Fundação Palmares

São 13 comunidades certificadas no estado de Santa Catarina: Toca/Santa cruz no município Paulo Lopes, Morro do Fortunato em Garopaba, Envenenada dos Negros Campos Novo, São Roque em Praia Grande, Campos dos Póli em Monte Carlos, Morro do Boi em Balneário Cambariu, Tabuleiro em Santo Amaro, Família Thomaz em Treze de Maio, Caldas do Cubatão em Aldeia, Vidal Martins em Florianópolis, Ilhotinha em Capivari de Baixo, Valongo em Porto Belo e Aldeia em Garopaba. Em 2004, 03 (três) comunidades receberam seus respectivos títulos: Envenenada dos Negros, Valongo e São Roque. A emissão de certificados para as comunidades dos remanescentes quilombolas do Estado de Santa Catarina, no período 2004 ao primeiro semestre de 2019, conforme os dados publicados na portaria $n^{\circ} 34 / 2019$, extenuo se em 2015. Os últimos certificados emitidos foram em 2013 e 2014, as comunidades Vidal Martins e Ilhotina. 
Comunidades quilombolas do Paraná

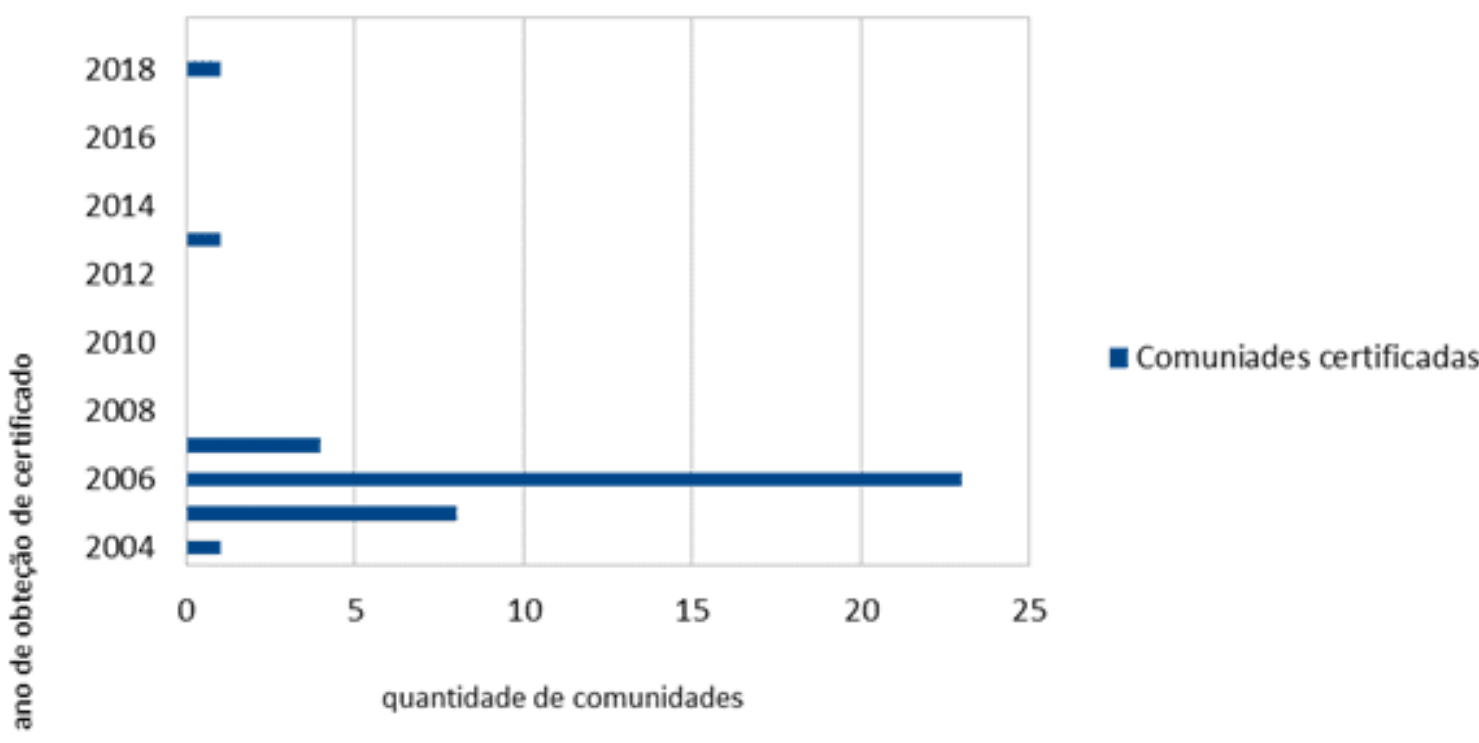

Fonte: Fundação Palmares

Conforme a notícia publica pelo jornal tribuna, 30/03/2019, por Elizangela Wroniski, o estado do Paraná tem 86 comunidades quilombolas. Deste número, de acordo com os dados publicados na portaria no $34 / 2019$ em 18/02/2019 soma apenas 38 comunidades certificadas. O estado do Paraná, em 2006, teve 23 comunidades que obtiveram os seus respectivos certificados de suas terras. Em 2007, mais 04 comunidades. Desde então, apenas 02 comunidades solicitaram o documentos, em 2013, Tobias Ferreira localizados no município de Palmas e, em 2018, Família Xavier do município de Arapoti. 


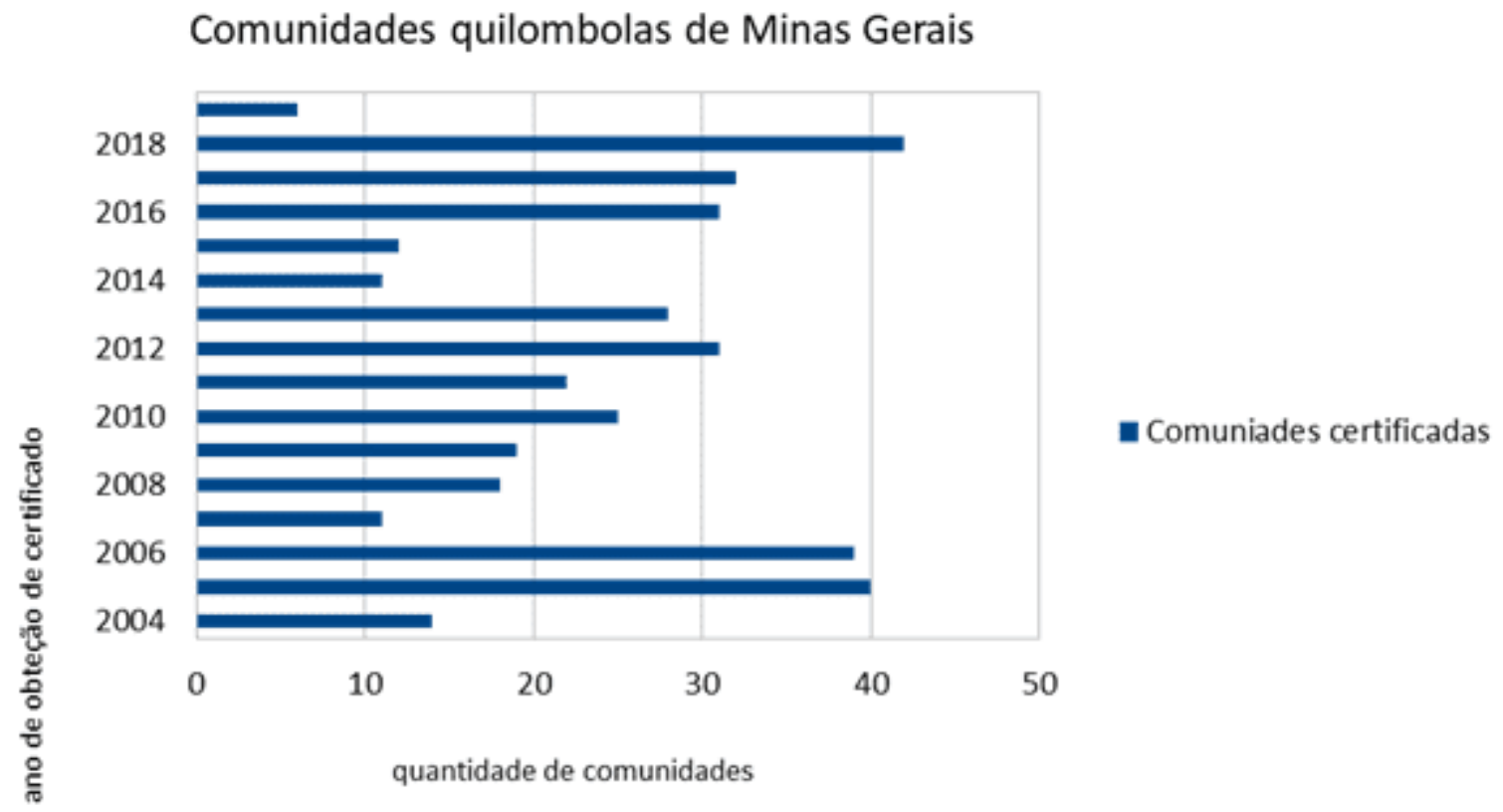

Fonte: Fundação Palmares

O estado de Minas Gerais tem 381 comunidades certificadas, conforme os dados publicados na portaria № 34/2019 em 18/02/2019. O estado tem mais de 800 comunidades sem os respectivos títulos. Em 2005, o estado teve 40 comunidades certificadas, correspondendo a 10,49 \% de comunidades até então. No ano seguinte, o estado quase atingiu o mesmo número, sendo 39 comunidades que receberam o reconhecimento dos seus territórios, sendo 10,23\%. Entre 2007 a 2017 estes números oscilaram para menos certificados obtidos. Contudo, as conquistas de certificados em 10 anos (2007 a 2017) correspondem a 62,99\%. Uma ação em 2018, do governador do Estado de Minas Gerais, Fernando Pimentel, deu concessão de terras aos remanescentes do estado. Ele assinou um decreto que segundo a notícia do jornal IOF de Minas, em 2 de abril de 2019, "é um ato inédito no estado". A notícia se refere a uma ação de titulação coletiva de terras em 2018. O decreto, assinado pelo governador liberou 1.385 hectares para o território quilombolas. Com isso, no mesmo ano 42 comunidades ganharam reconhecimento, correspondendo $11,02 \%$. 
Comunidades quilombolas do Estado de São Paulo

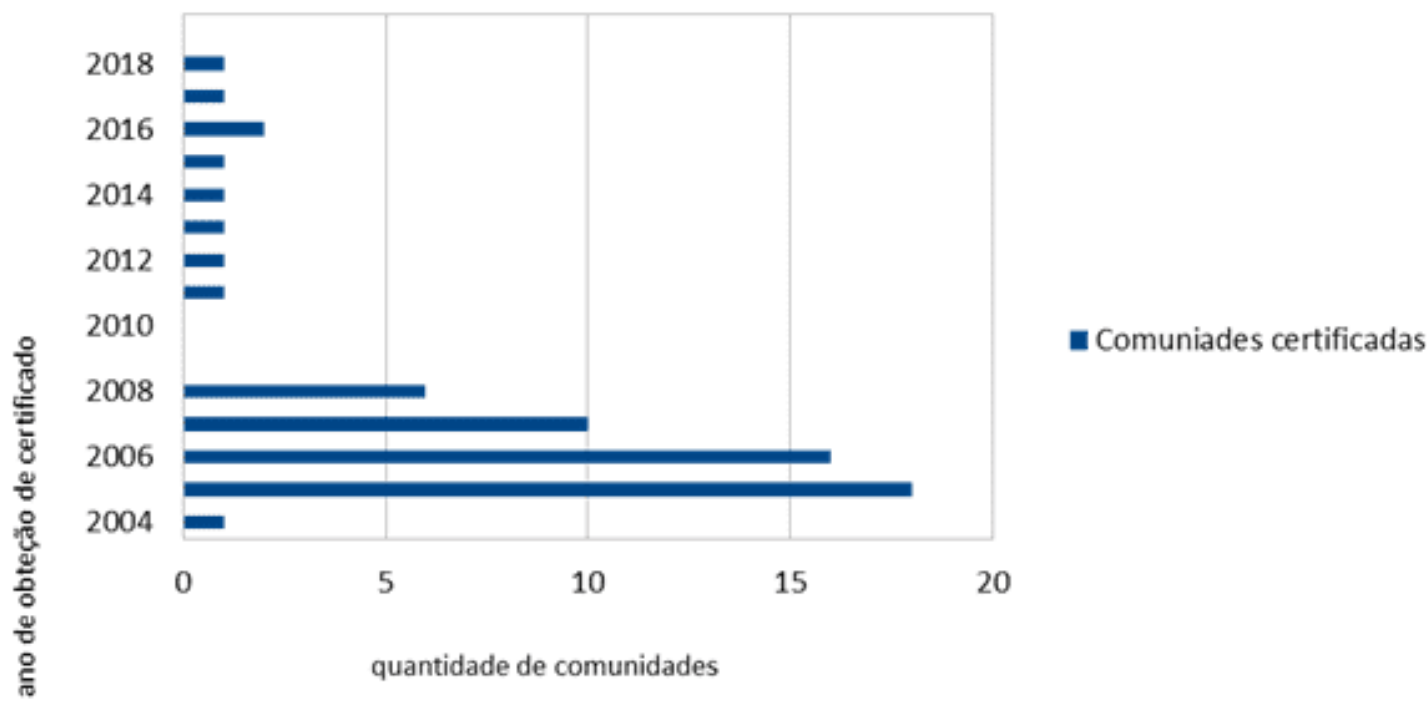

Fonte: Fundação Palmares

São 60 comunidades certificadas em São Paulo. Em 2005 o estado obteve 18 certificados, o maior número até então. No ano seguinte, este número caiu para 16 certificados obtidos. Os números para as comunidades do estado de São Paulo, entre 2004 a fevereiro de 2019 não são animadores. Desde 2005 os números de comunidade certificadas foram diminuindo, chegando apenas 01 comunidade em 2018.

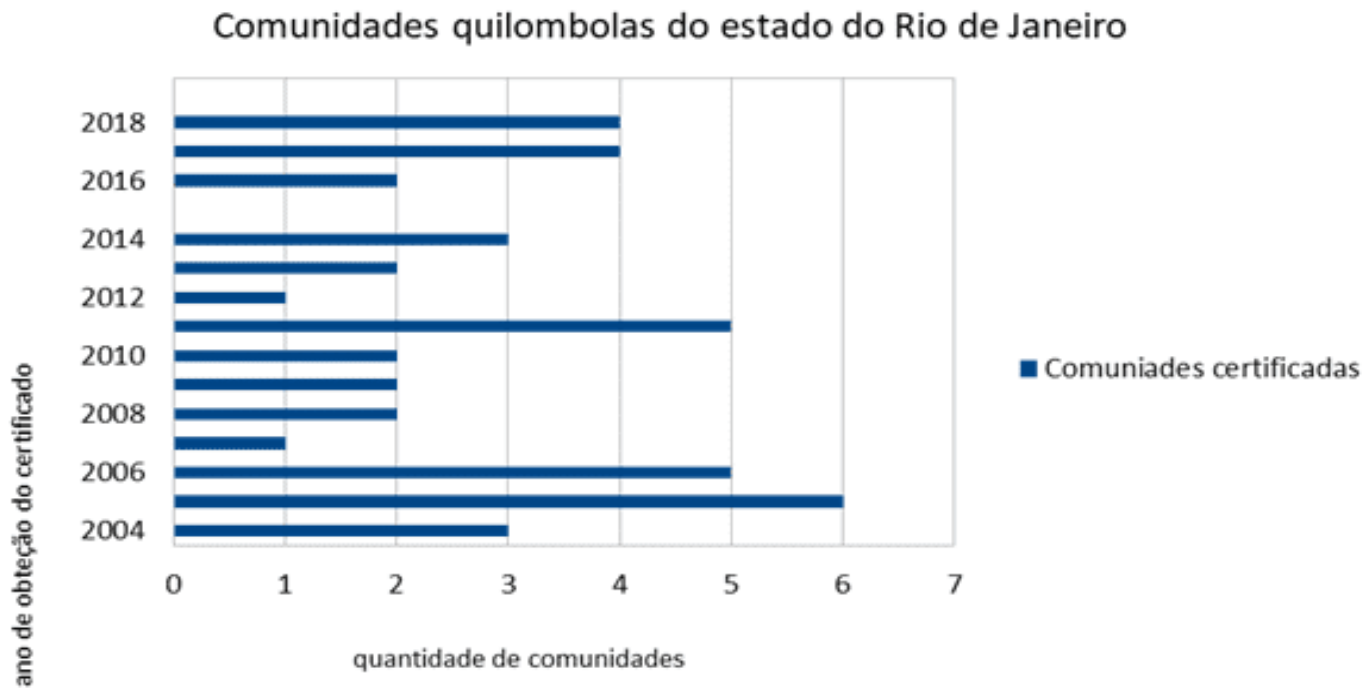

Fonte: Fundação Palmares

RC: 34733

Disponível em: https://www.nucleodoconhecimento.com.br/educacao/terras-quilombolas 
O estado do Rio de janeiro tem 42 comunidades certificadas. Os quilombos de Sacopã e Pedra do sal, certificados em 2004 e 2006, ambos concentrados em zona urbana, sofrem para conseguir os títulos de suas terras. Em 2005, foram certificadas 6 comunidades, um número não tão expressivo. Das 42 comunidades, apenas quatro possuem os títulos de suas terras. Em 2017 e 2018, o estado ganhou oito certificados.

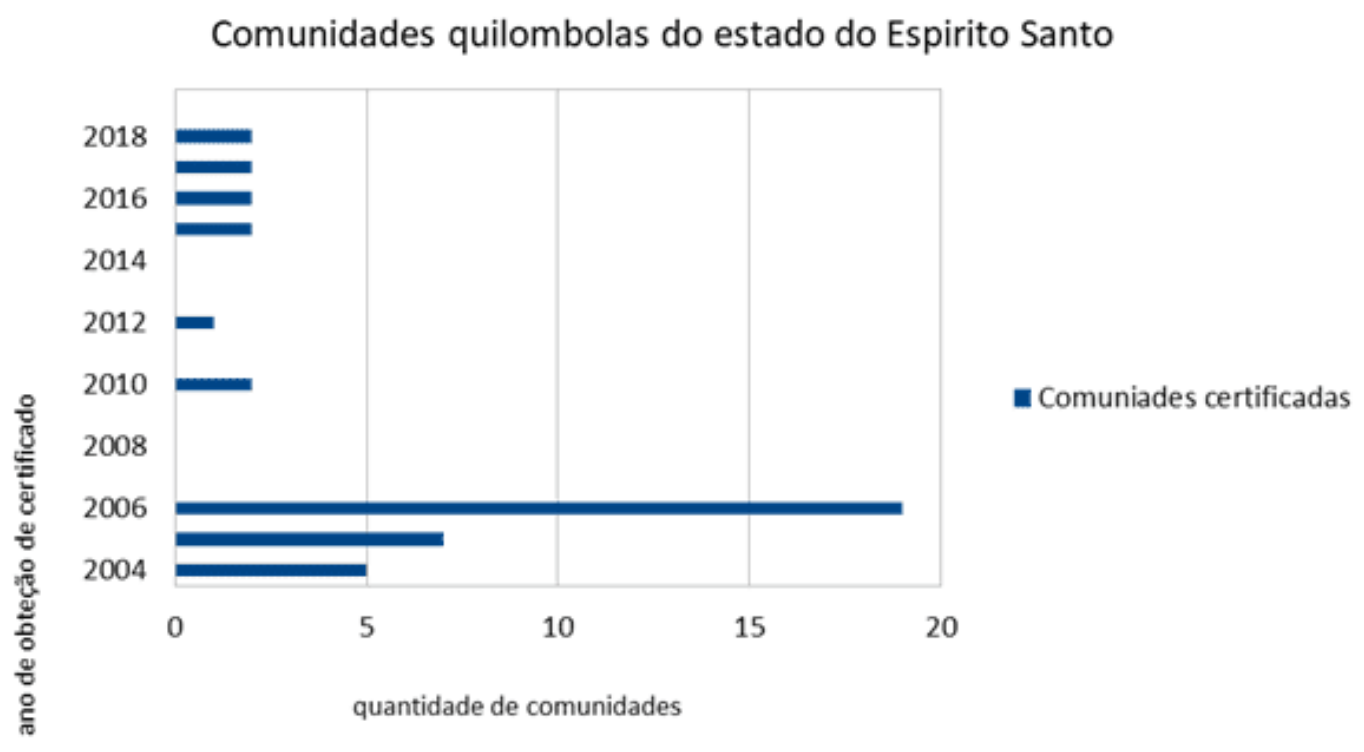

Fonte: Fundação Palmares

No estado do Espírito do Santo tem 42 certificados emitidos entre 2004 a 2019. Em 2006, 19 comunidades receberam seus respectivos certificados, este número representa $42,23 \%$ do total de certificados até o momento. O entre 2007 e 2009 , não houve reconhecimento de comunidades no estado. Entre 2015 a fevereiro de 2019 o estado teve apenas oito comunidades reconhecidas. 
Comunidades quilombolas de Goiás

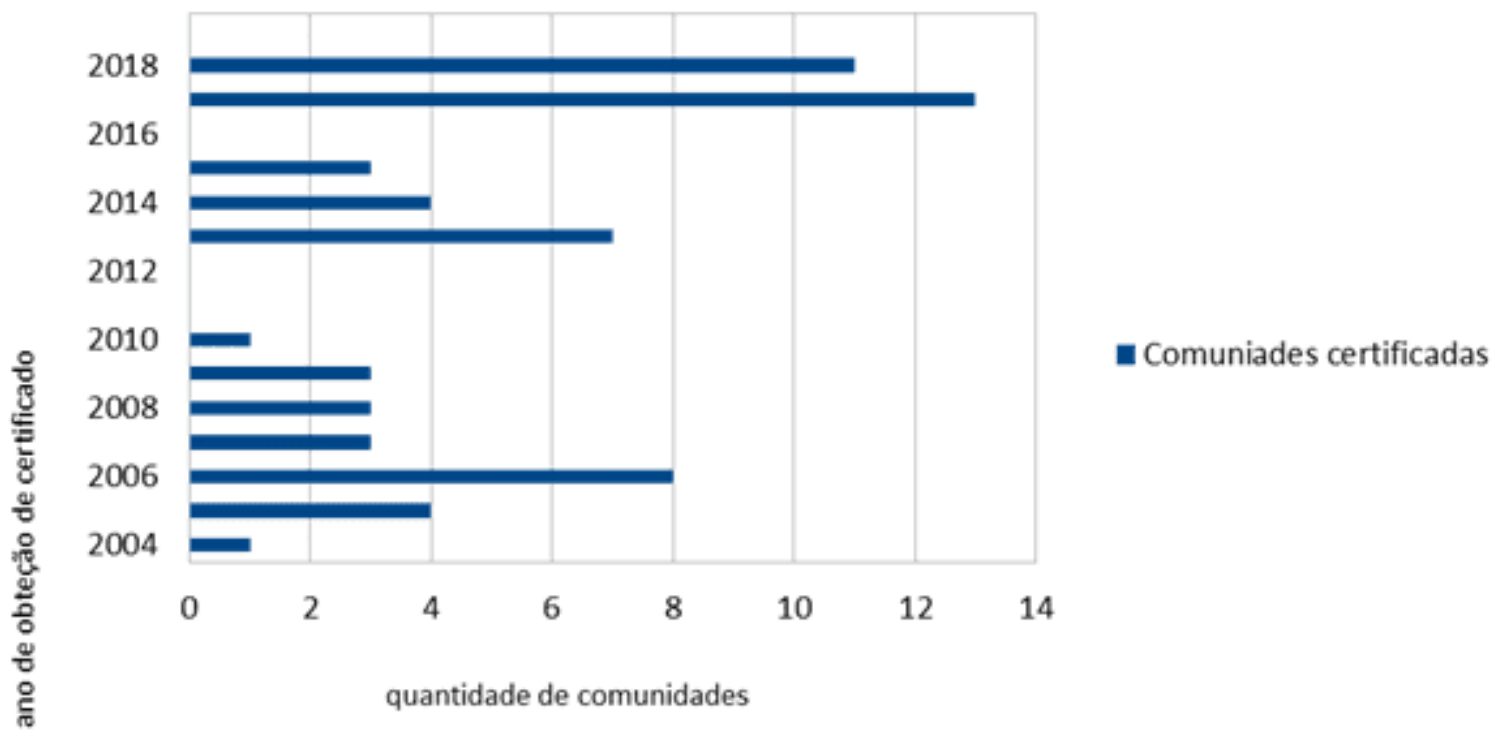

Fonte: Fundação Palmares

O estado de Goiás tem 64 comunidades certificadas. No ano de 2017 e 2018 o estado teve o maior número de certificados emitidos, um total de 24 comunidades tiveram seus receptivos títulos, número que reapresenta $37,5 \%$ do total de comunidades até então certificadas.

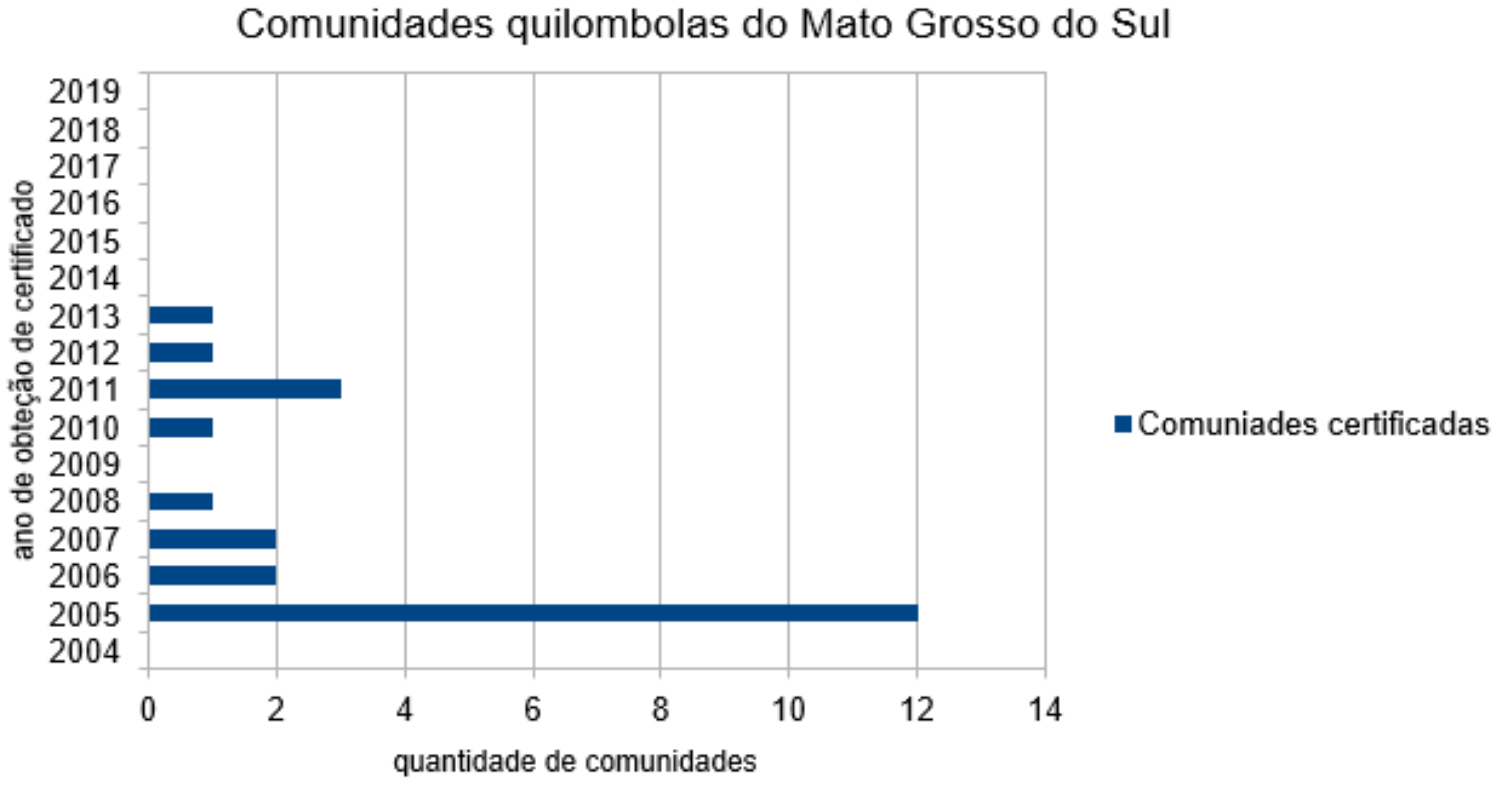

Fonte: Fundação Palmares 
O estado tem 23 comunidades reconhecidas. Em 2005, teve 12 comunidades certificadas, número que representa $53.1 \%$ dos certificados emitidos. Desde 2013, ano que o estado teve apenas 01 certificado, não teve mais nenhuma comunidade reconhecida.

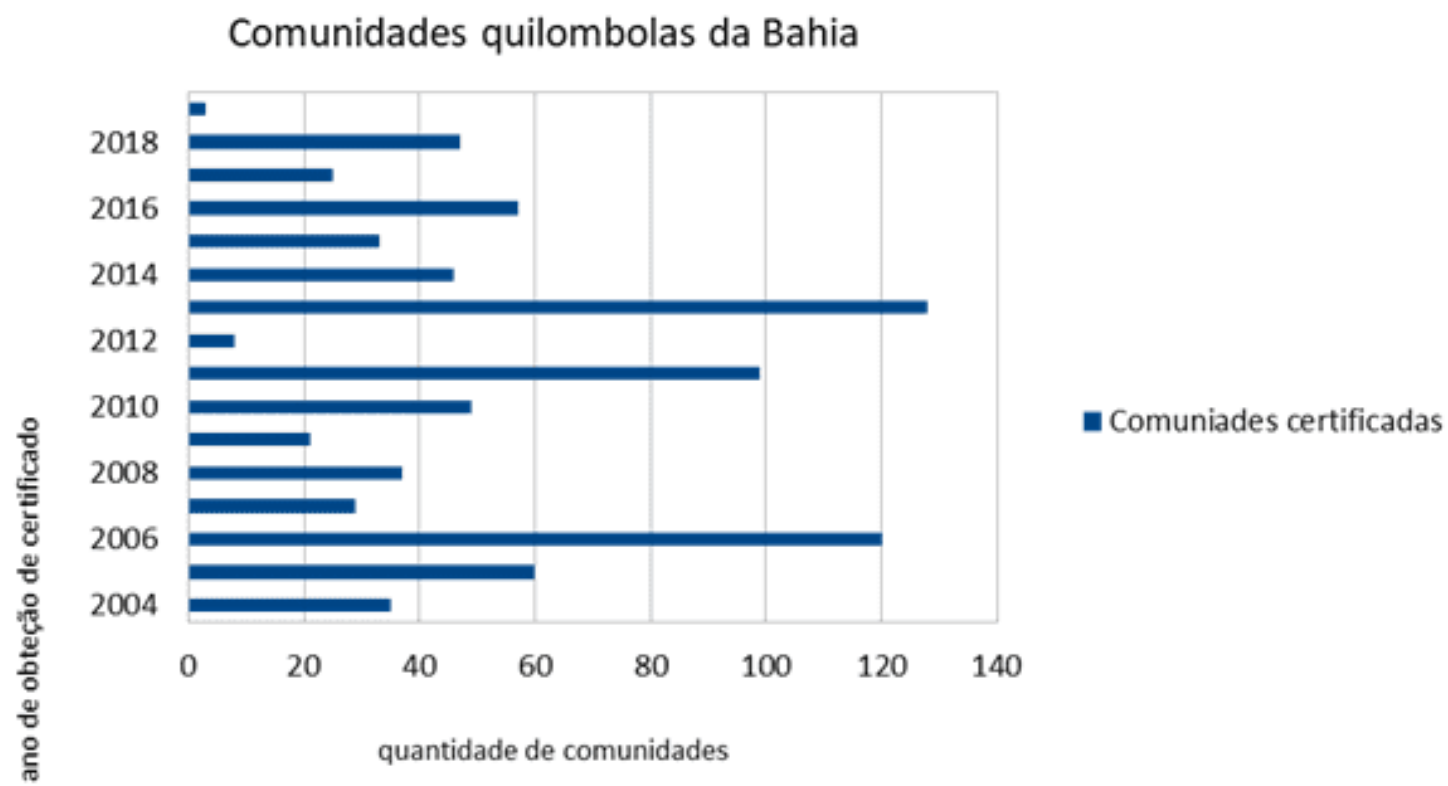

Fonte: Fundação Palmares

O estado tem 797 comunidades certificadas, é o maior número de comunidades no Brasil. Em 2006, o estado teve 120 comunidades reconhecidas, soma que corresponde a 15\% do total. Em 2013, o estado supera, 128 comunidades receberam os seus certificados, número que corresponde 16\%. Entre 2014 a fevereiro de 2019, o estado teve 211 certificados emitidos, isto é, $26,47 \%$ de certificados emitidos. 
Comunidades quilombolas do Mato Grosso

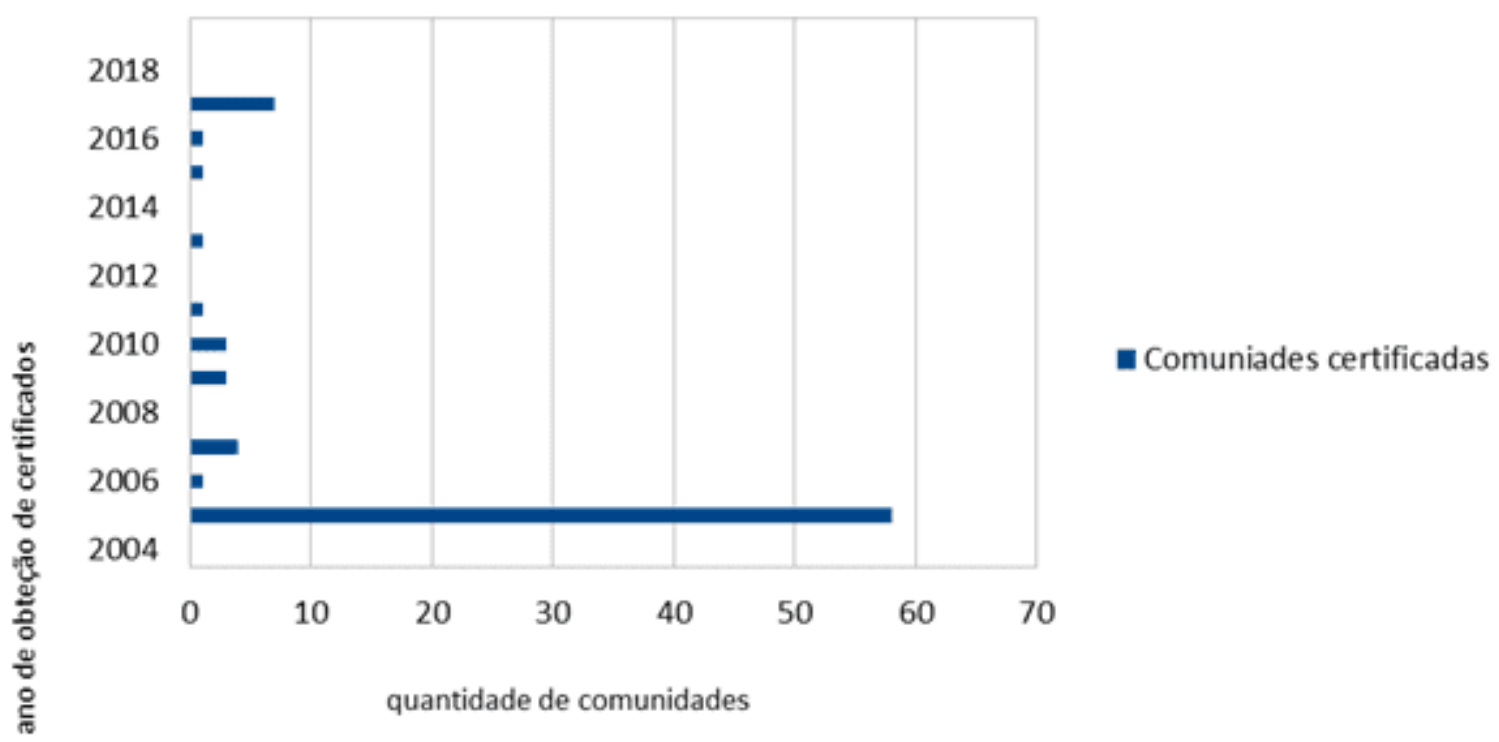

Fonte: Fundação Palmares

O estado do Mato Grosso tem 80 comunidades certificadas. Em 2005, o estado teve 58 certificados emitidos, este número corresponde a $72,5 \%$ das comunidades reconhecidas no estado. Entre 2006 a fevereiro de 2019 o estado obteve 22 certificados.

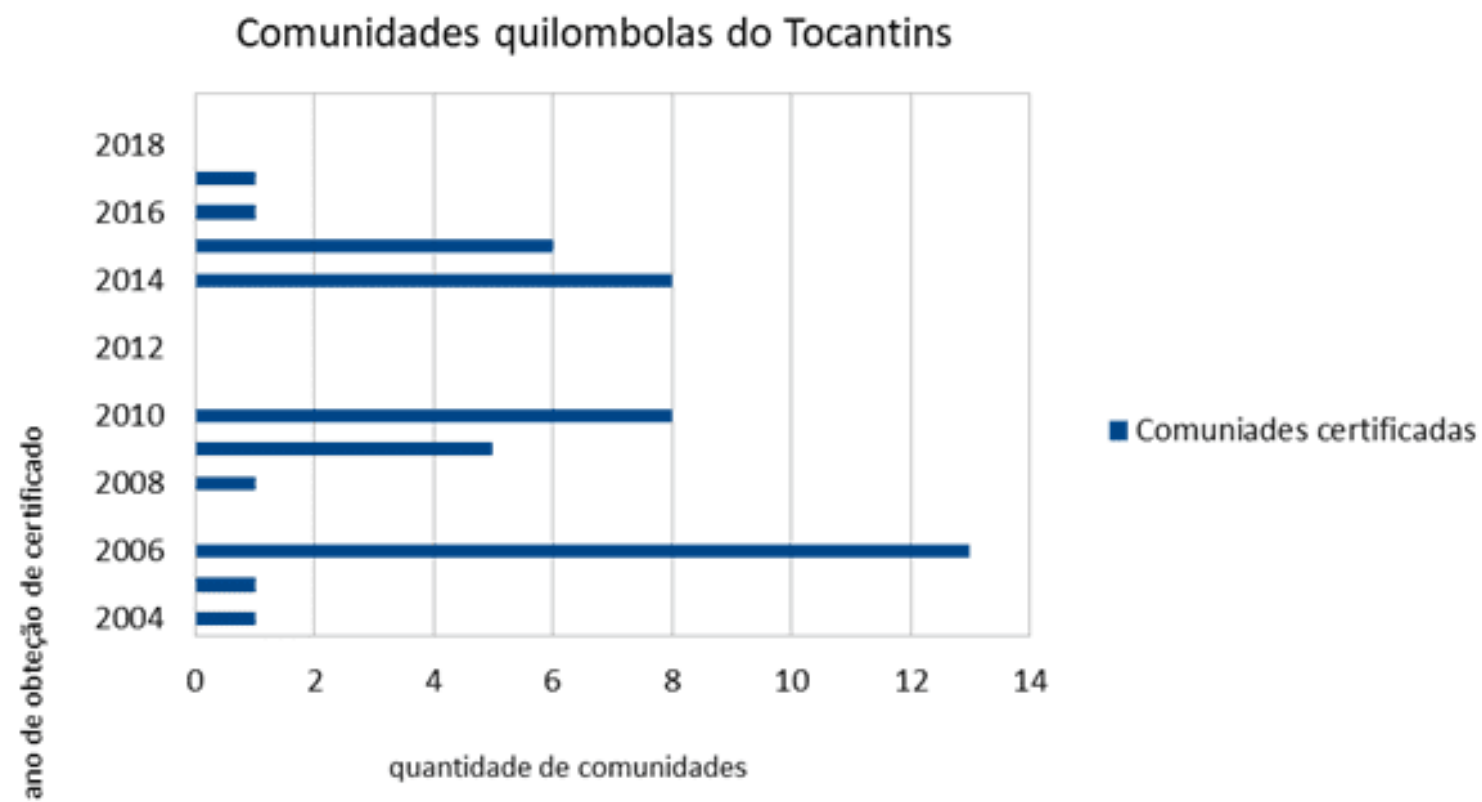

Fonte: Fundação Palmares

RC: 34733

Disponível em: https://www.nucleodoconhecimento.com.br/educacao/terras-quilombolas 
O estado tem 45 comunidades quilombolas certificadas. Em 2006, foram 13 comunidades reconhecidas, este número representa $28.8 \%$ dos certificados emitidos para o estado no período de 2004 a 2019. Nos últimos anos não foi reconhecida nenhuma comunidade. Entre 2007 e 2017 foram 30 comunidades que receberam seus certificados.

Comunidades quilombolas do Rondônia

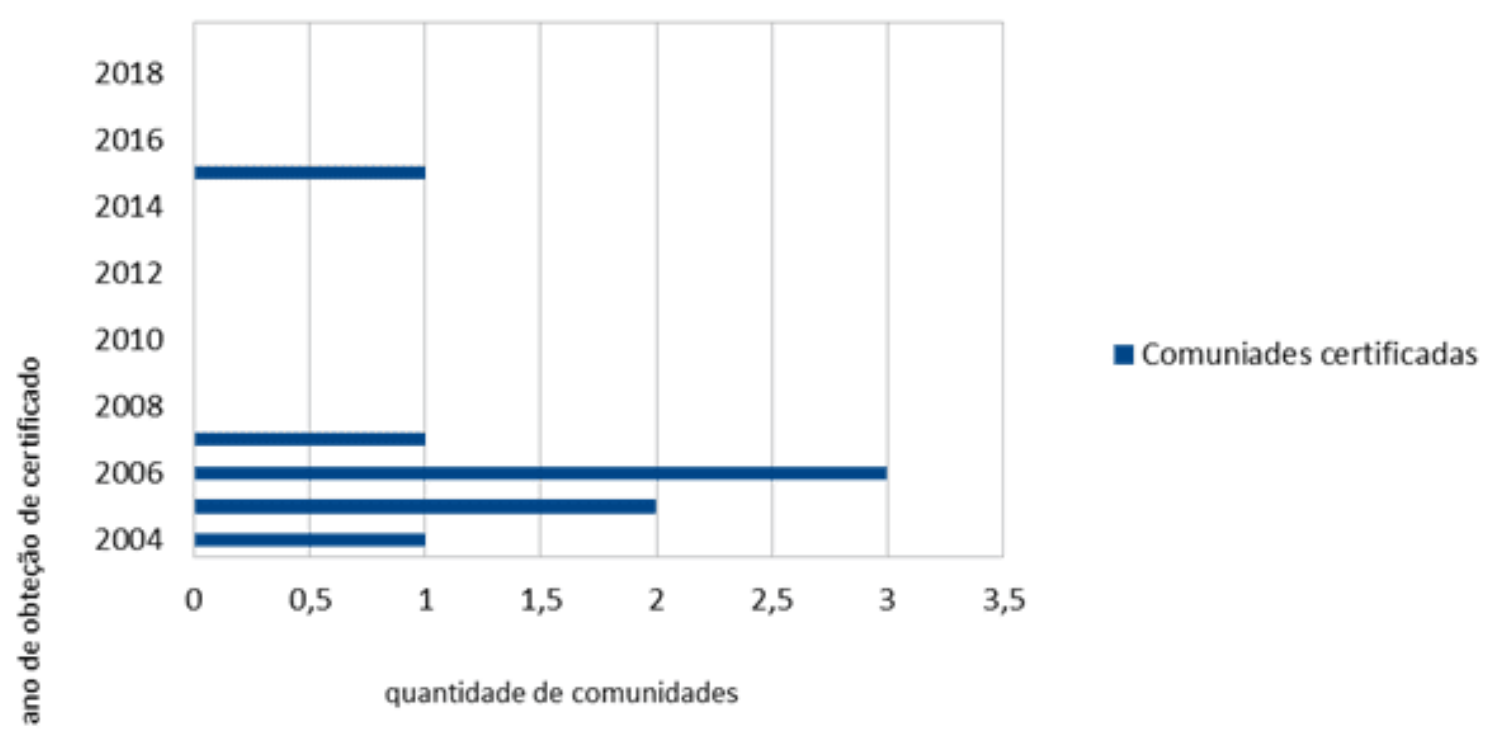

Fonte: Fundação Palmares

Com apenas 08 comunidades certificadas, Rondônia é um dos estados que apresenta o menor número de comunidades quilombolas reconhecidas. Os primeiros certificados foram emitidos entre 2004 a 2007, foram sete comunidades que receberam seus certificados. Desde então, o estado apenas tem mais 01 comunidade reconhecida em 2015. 
Comunidades quilombolas do Amazonas

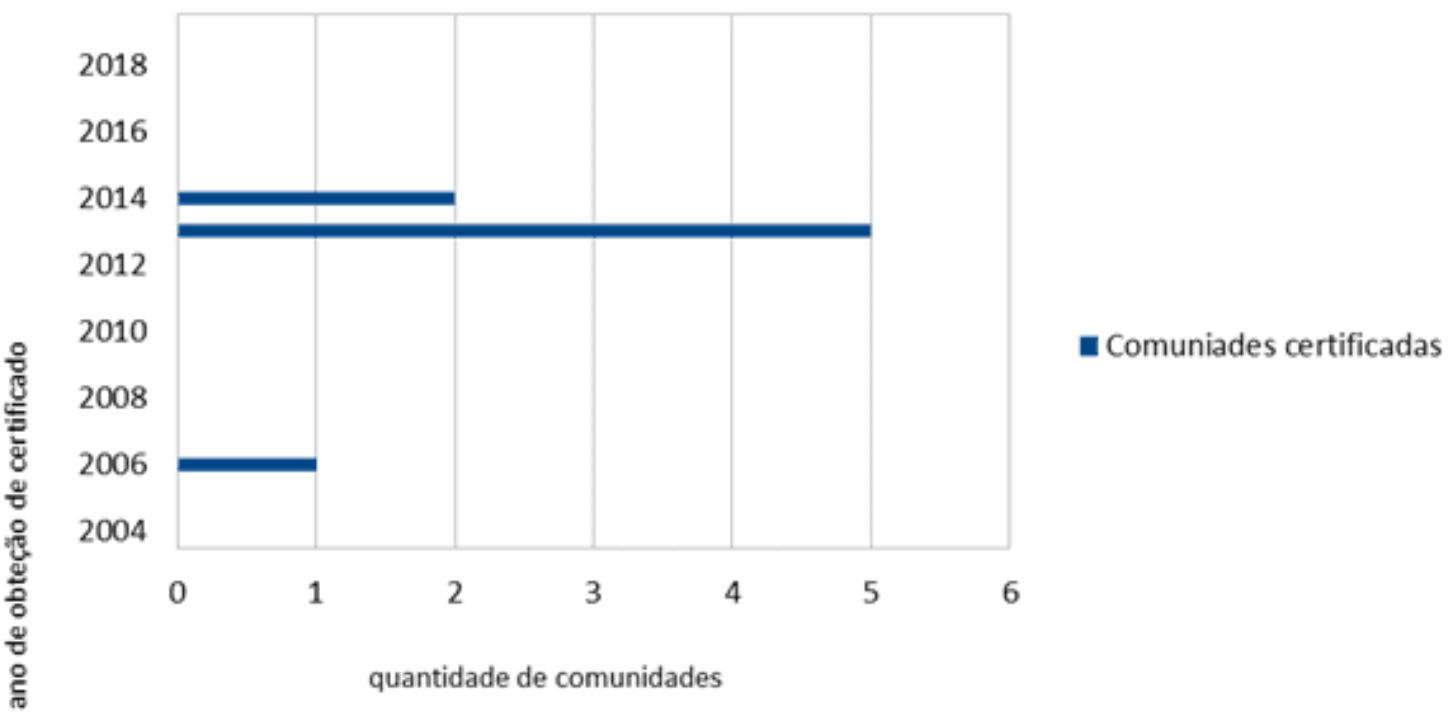

Fonte: Fundação Palmares

O estado do Amazonas em 2006 teve apenas 01 certificado emitido. Em 2013 e 2014 foram reconhecidas mais 07 comunidades. Conforme os dados da Fundação Palmares o estado tem apenas 08 comunidades.

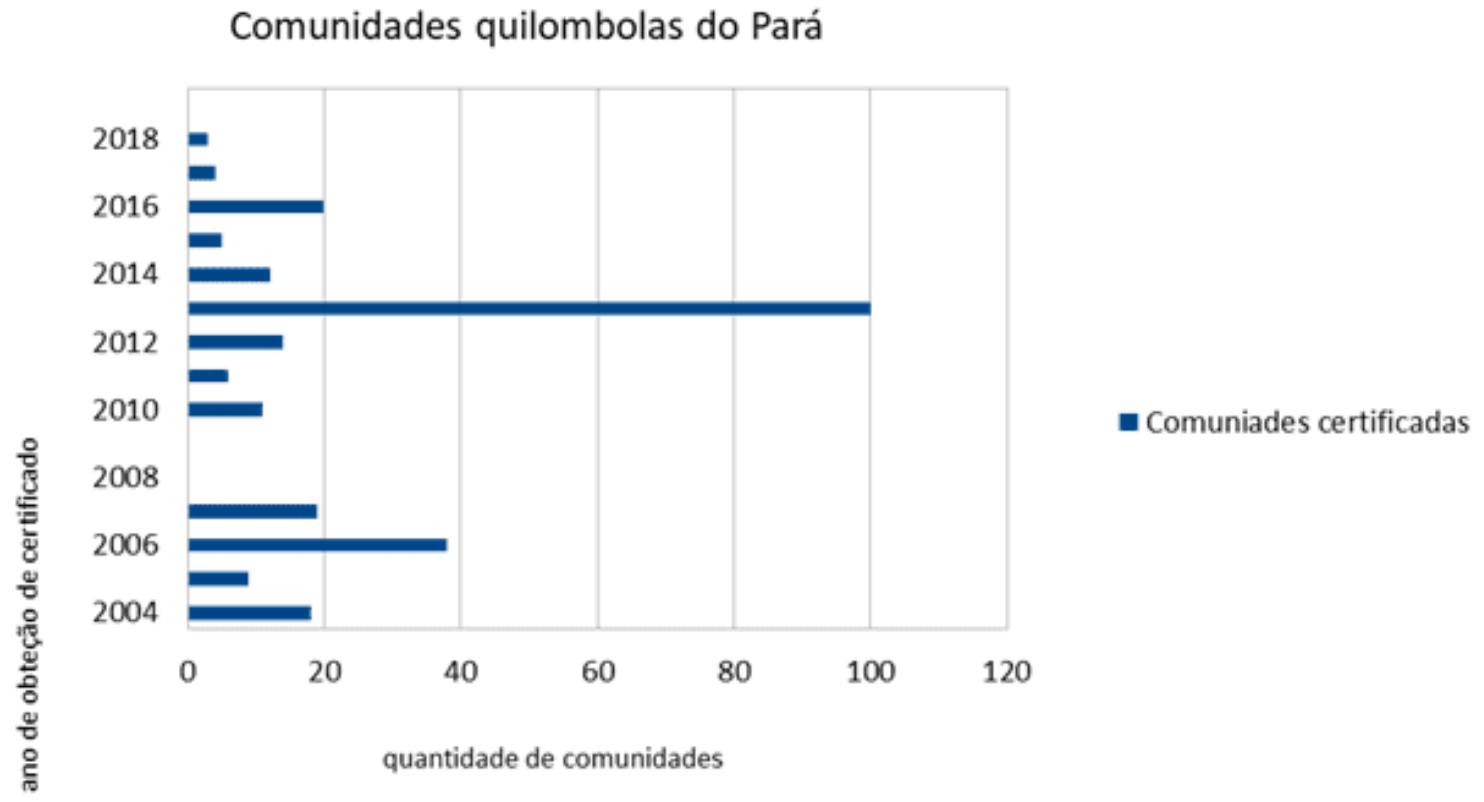

Fonte: Fundação Palmares 
O estado do Pará tem 259 comunidades quilombolas certificadas. Em 2013, o estado teve 100 comunidades que receberam seus certificados, um número que representa $38.6 \%$ do total. Entre 2004 a 2012, foram emitidos 115 certificados, isto corresponde a 44.4\%. Entre 2014 e 2019, o estado obteve 44 certificados.

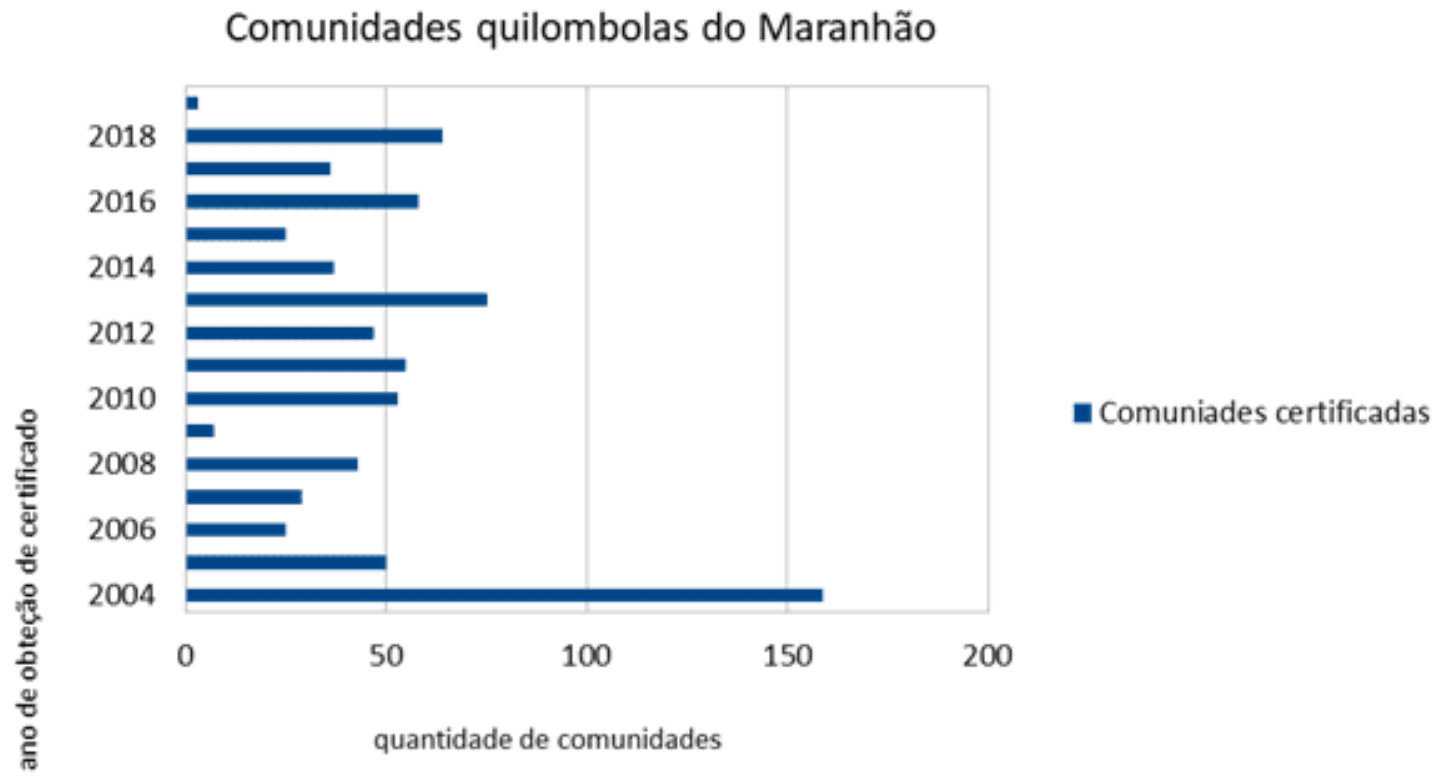

Fonte: Fundação Palmares

O estado do Maranhão é o segundo estado com maior número de certificados. O estado tem 766 certificados. Em 2004, foram certificadas 159 comunidades que corresponde a $20.75 \%$ do total de comunidades reconhecidas do Estado. O segundo ano de maior expressividade na emissão de certificados foi em 2013, no estado foram reconhecidas 75 comunidades, isto é, 9.8\%. Entre 2005 e 2012 foram emitidos 309 certificados, um total de $40.34 \%$. Entre os anos de 2014 e 2019 (fevereiro), o estado do Maranhão obteve 223 certificados, número que representa $29.11 \%$ de certificados até então emitidos. 


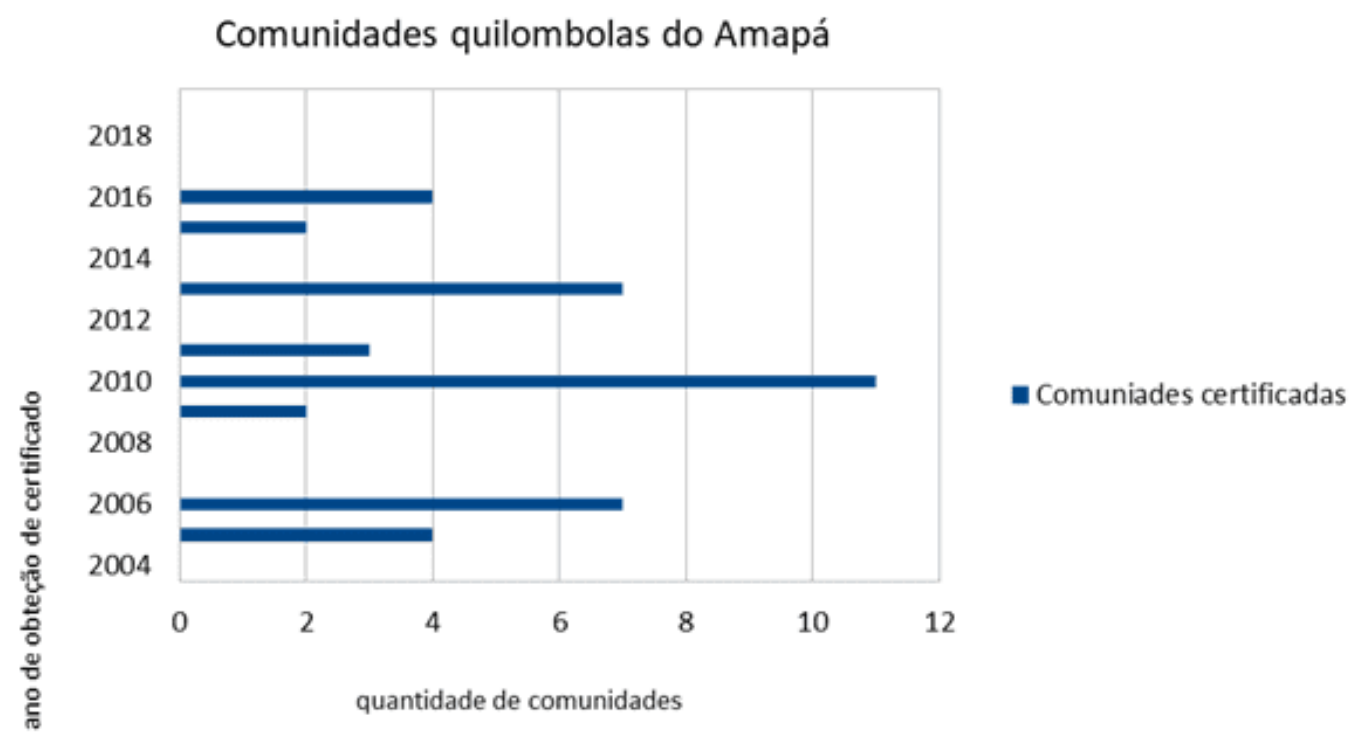

Fonte: Fundação Palmares

O estado do Amapá tem 40 comunidades certificadas pela Fundação Palmares. Em 2010, o estado teve 11 certificados emitidos, este número corresponde a $27.50 \%$ dos certificados emitidos entre 2004 a fevereiro de 2019. Entre 2004 e 2009 foram certificadas 13 comunidades, isto $32.5 \%$ do total de certificados. Entre 2011 e 2018 , o estado obteve o reconhecimento de 16 comunidades, número que corresponde $40 \%$ do total.

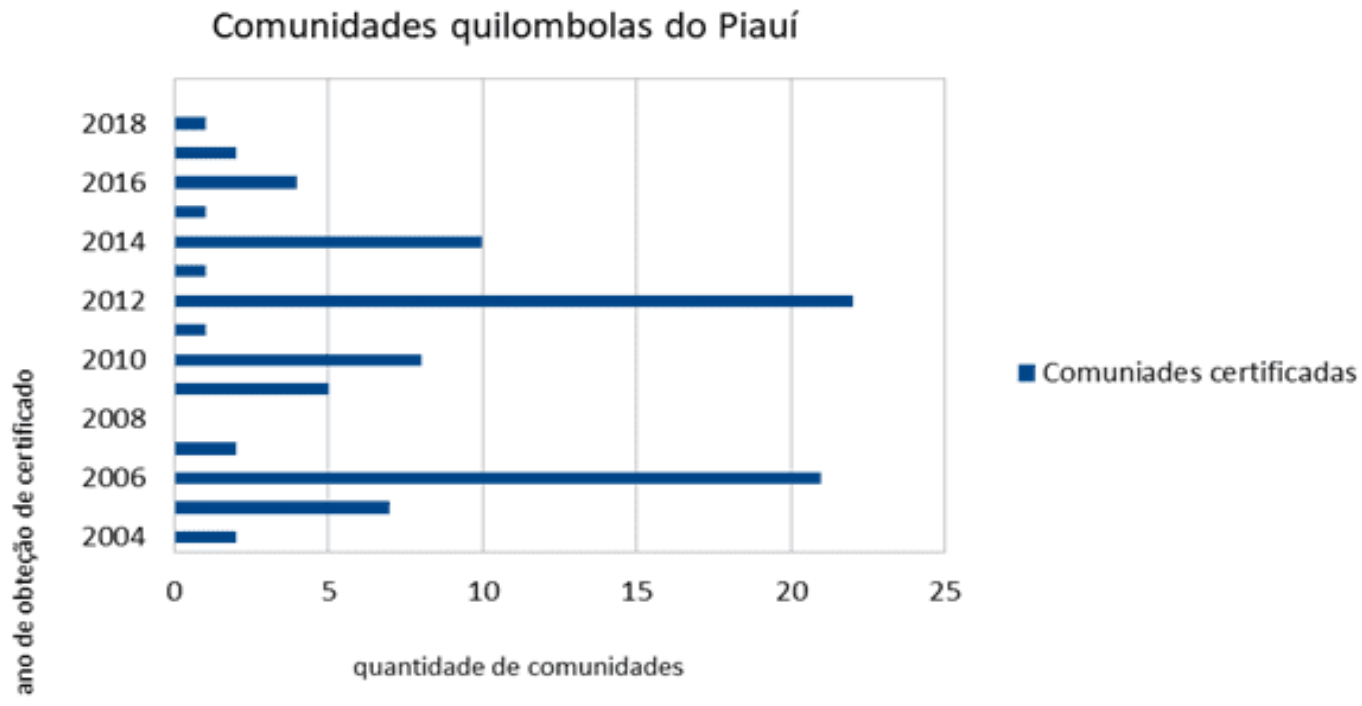

Fonte: Fundação Palmares 
O estado do Piauí tem 87 comunidades de remanescentes quilombolas reconhecidas. No ano de 2012, o estado teve 22 comunidades certificadas pela Fundação Palmares, correspondendo a $25.28 \%$ do total, foi ano mais expressivo em termos de certificados emitidos no estado. Entre 2004 e 2011, foram emitidos 46 certificados, estes correspondem $52.87 \%$ do total. Entre 2013 e fevereiro de 2019, foram certificadas 19 comunidades, número que corresponde a $21.83 \%$ das comunidades reconhecidas do Estado.

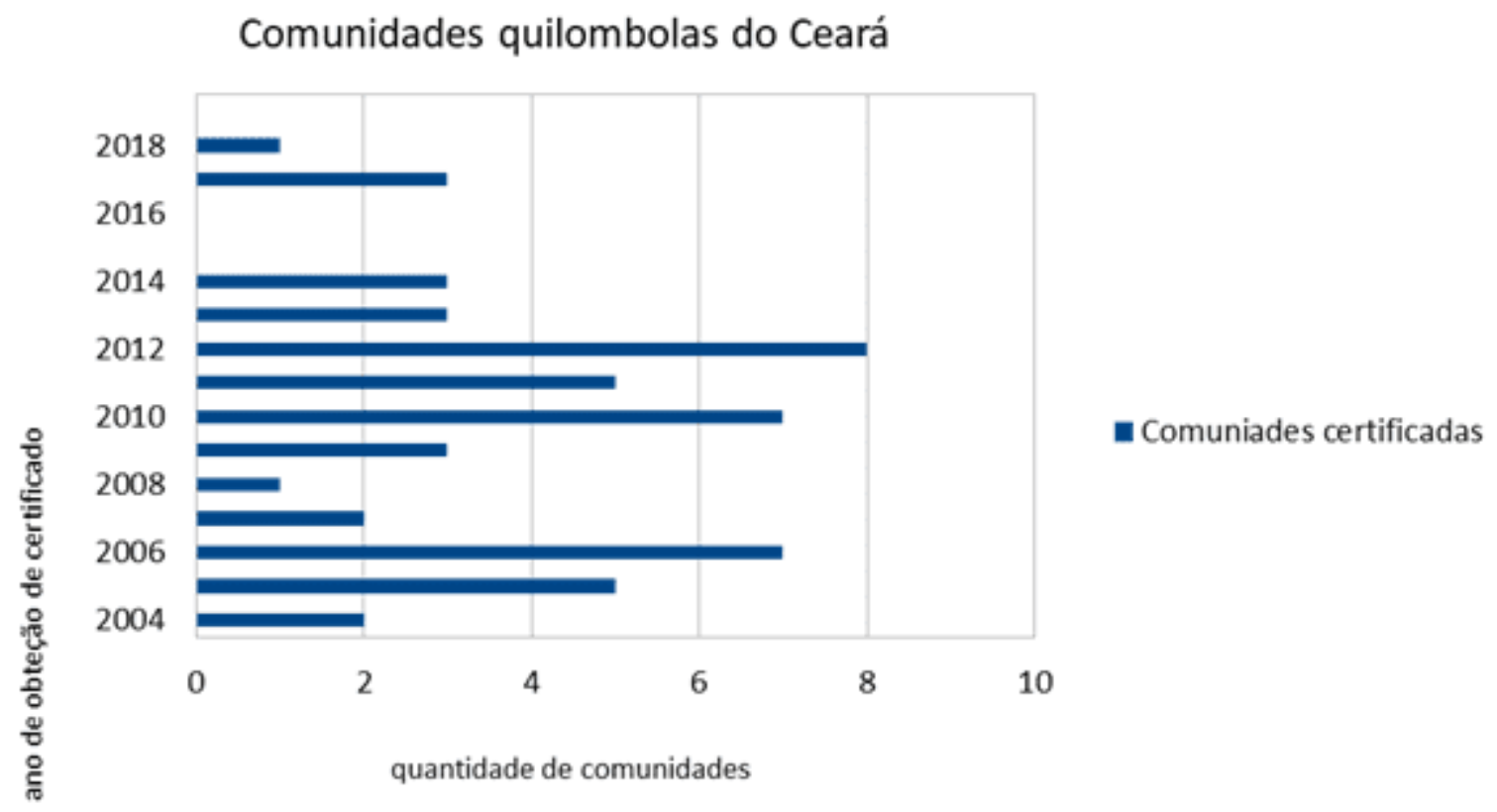

Fonte: Fundação Palmares

O estado do Ceará tem 50 comunidades reconhecidas pela Fundação Palmares. Em 2012, o estado teve o maior número de certificados emitidos, 12 certificados foram expedidos para as comunidades até então não reconhecidas número que corresponde a $24 \%$ do total. Entre 2004 e 2011, foram reconhecidas 32 comunidades, isto é, $64 \%$. Entre 2013 e fevereiro de 2019, 10 comunidades receberam seus certificados. 


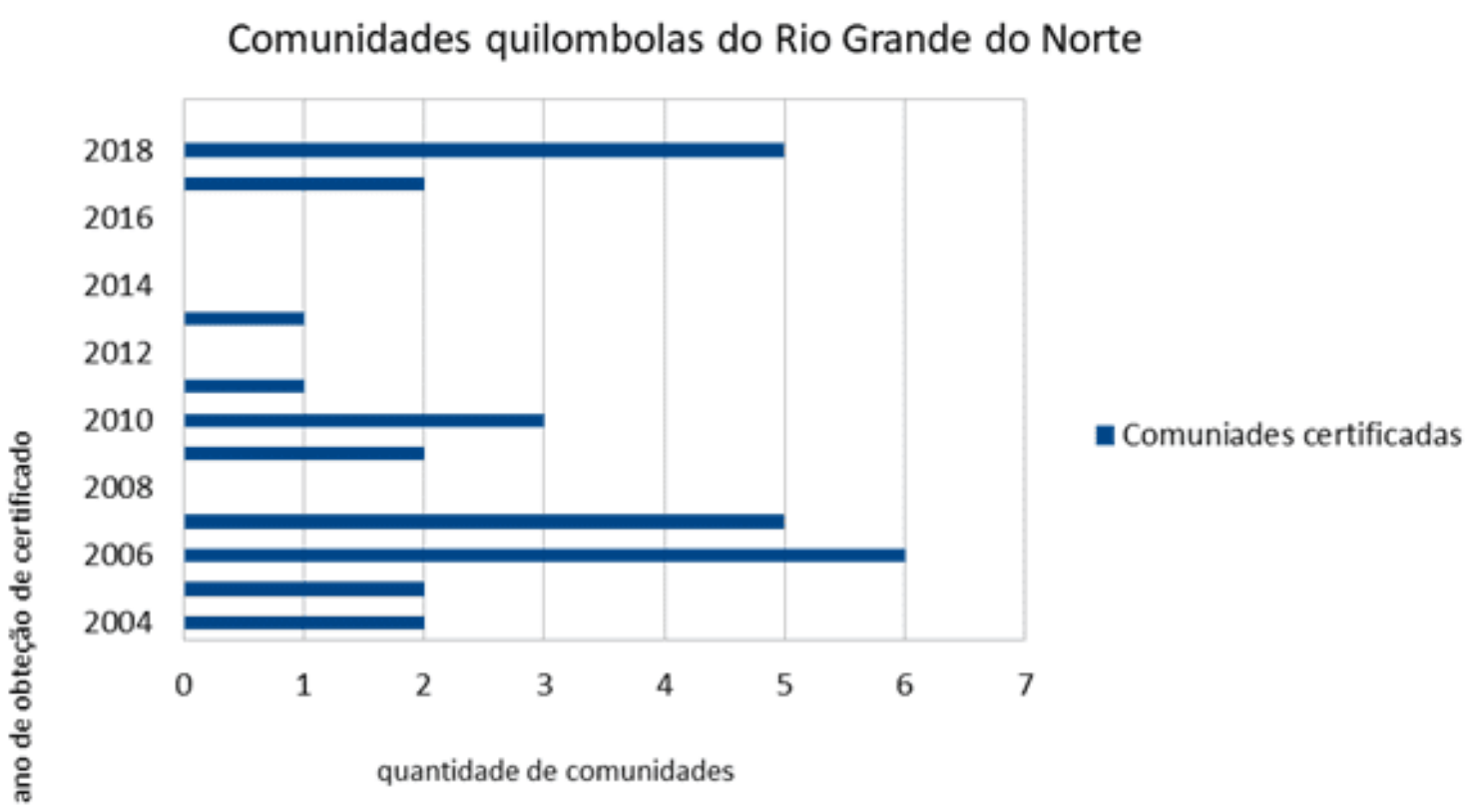

Fonte: Fundação Palmares

O estado tem 29 comunidades reconhecidas. Em 2006, foram expedidos 06 certificados, correspondendo a $20.68 \%$ é o ano que o estado recebeu mais certificados. Entre 2004 e 2005, apenas 04 comunidades foram cerificadas. Entre 2007 a fevereiro de 2019, foram expedidos 19 certificados, estes números representam um total de $65.51 \%$ das comunidades quilombolas do estado do Rio Grande do Norte.

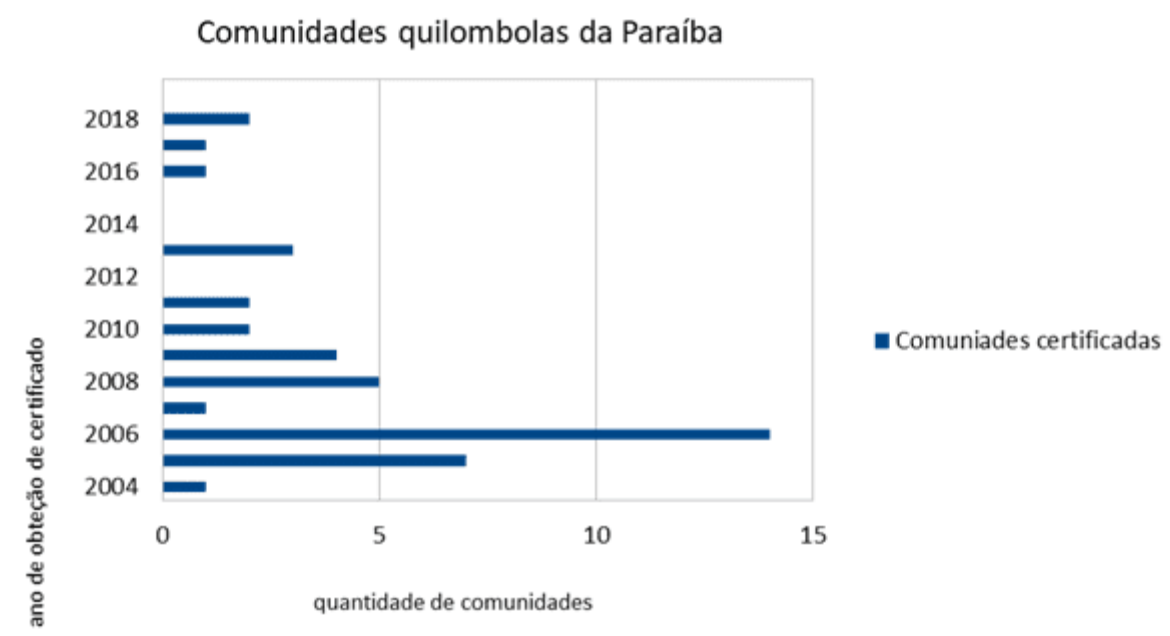

Fonte: Fundação Palmares 
No estado da Paraíba tem 43 comunidades certificadas. Em 2006, para o estado, foram expedidos 14 certificados, estes números expressivos, representa $32.55 \%$ do total de comunidades. Ente 2004 e 2005, foram apenas 8 comunidades que receberam certificados, 18.60\% . Entre 2007 e fevereiro de 2019, o estado teve 23 comunidades reconhecidas, este número corresponde a $53.48 \%$ do total de certificados obtidos até então.

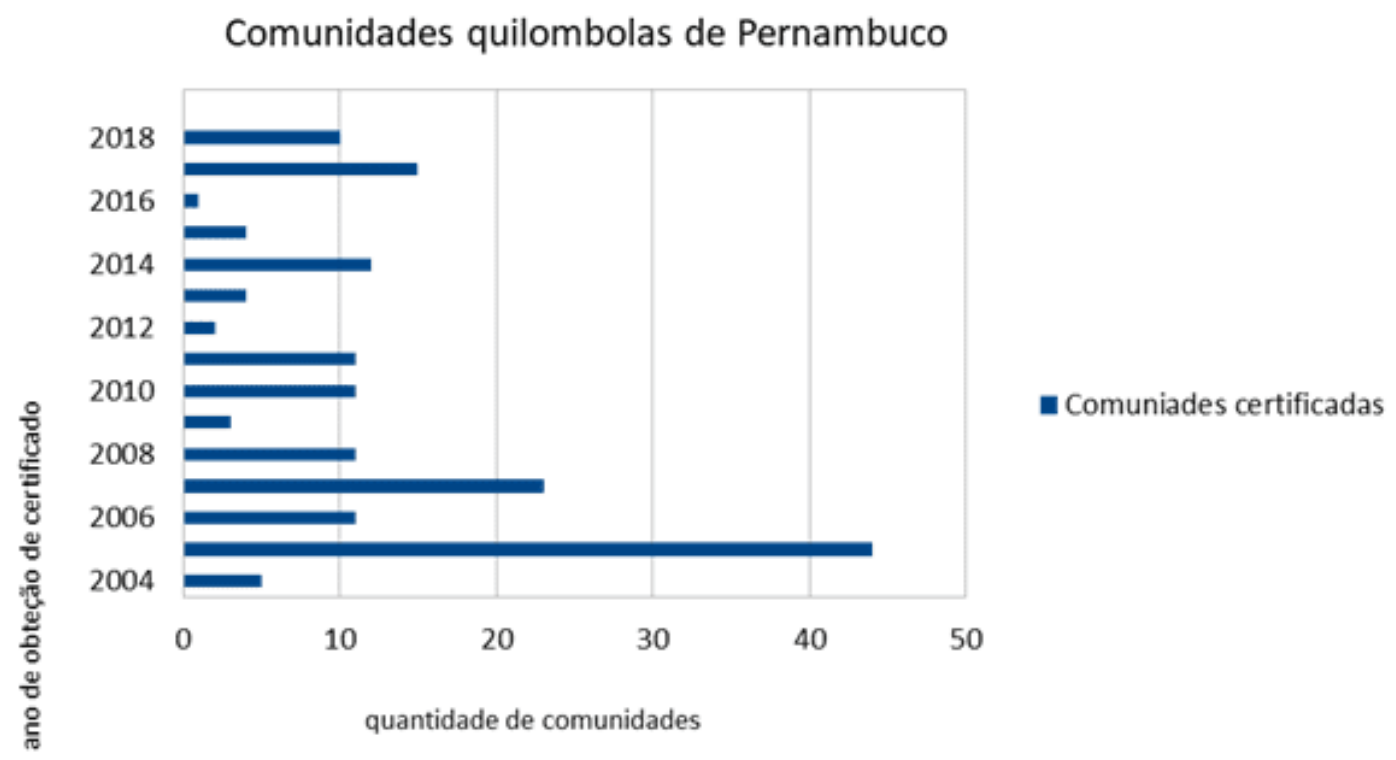

Fonte: Fundação Palmares

O estado possui 161 comunidades reconhecidas. No ano 2005, o estado recebeu 44 certificados, números que correspondem a 27.32\% do total. Em 2004, apenas 05 comunidades foram reconhecidas. Entre 2007 e 2012, foram certificadas 61 comunidades, 37.88\%. Entre 2013 a fevereiro de 2019, o estado recebeu 46 certificados, um total de $28.57 \%$. 
Comunidades quilombolas de Alagoas

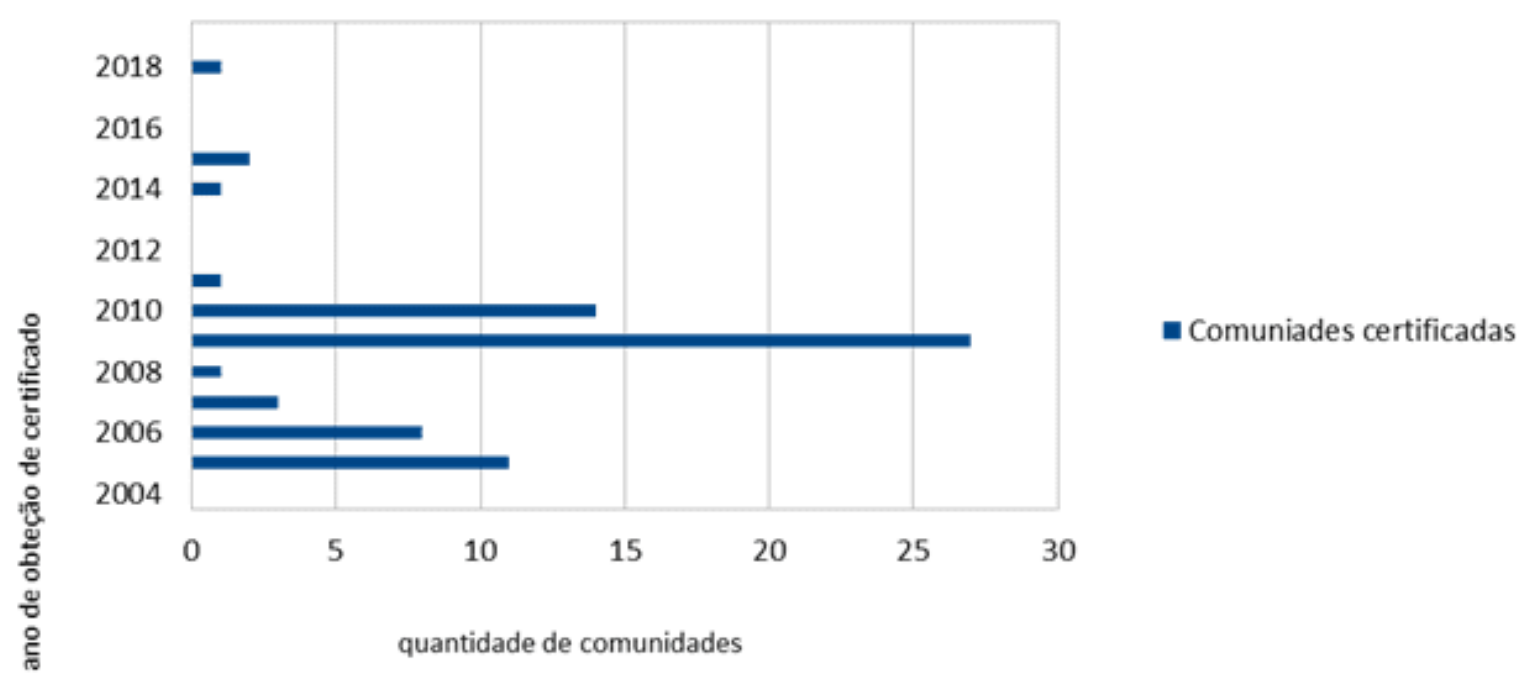

Fonte: Fundação Palmares

No estado de Alagoas tem 69 comunidades certificadas. Em 2009, o estado recebeu - maior número de certificados, 27 comunidades foram reconhecidas, correspondendo a 39.13\% do total. Entre 2004 e 2008, foram expedidos 23 certificados para o estado, este número corresponde a $33.33 \%$ das comunidades do estado. Entre 2010 e fevereiro de 2019, o estado recebeu 21 certificados, isto é, $30.40 \%$ das comunidades remanescentes quilombolas até então reconhecidas.

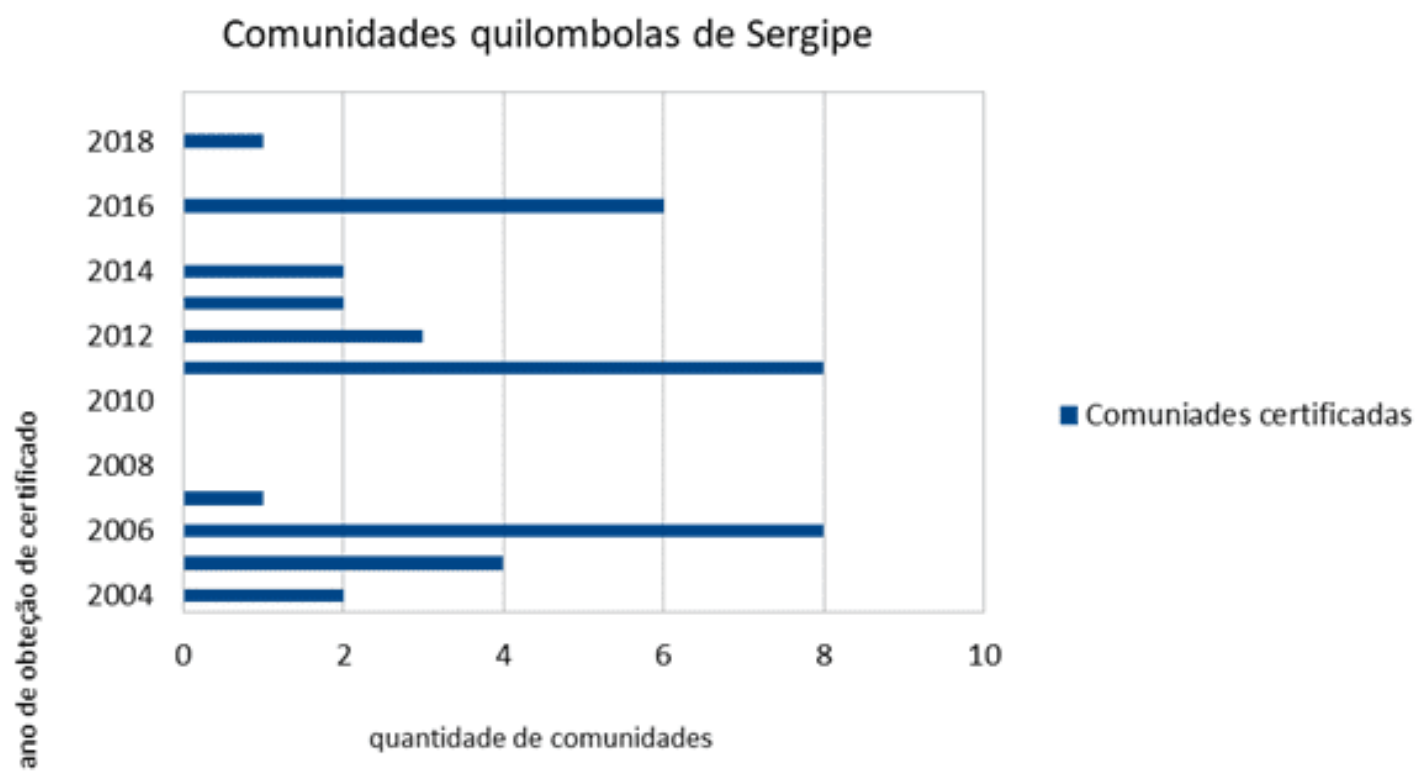

Fonte: Fundação Palmares

RC: 34733

Disponível em: https://www.nucleodoconhecimento.com.br/educacao/terras-quilombolas 
No estado de Sergipe tem 37 comunidades de remanescentes quilombolas reconhecidas. Entre 2004 e 2010, o estado recebeu 15 certificados, número que corresponde a $40.55 \%$ do total de certificados expedidos. Entre 2011 e fevereiro de 2019, foram 22 comunidades certificadas, números que correspondem a 59.45\%.

\section{RECURSOS PÚBLICOS DESTINADOS A TITULAÇÃO DE TERRAS}

Na responsabilidade do INCRA, têm mais de 1,7 mil pedidos de titulação de terras de remanescentes quilombolas. O governo destinou menos de 1 milhão de reais, valor este insuficiente para atender as demandas. Desse total, 32 áreas de 12 comunidades quilombolas já foram reconhecidas, tiveram o decreto de desapropriação assinado, e aguardam apenas a titulação. A tabela abaixo mostra os valores destinados ao INCRA para titulação de terras.

Tabela: recursos públicos repassados ao INCRA

\begin{tabular}{|l|l|l|l|l|l|l|l|l|}
\hline $\mathbf{5 4 , 2} \mathbf{~ m i}$ & $\mathbf{2 4 , 2} \mathbf{~ m i}$ & $\mathbf{5 0} \mathbf{~ m i}$ & $\mathbf{2 5} \mathbf{~ m i}$ & $\mathbf{2 5} \mathbf{~ m i}$ & $\mathbf{2 5} \mathbf{~ m i}$ & $\mathbf{5} \mathbf{~ m i}$ & $\mathbf{3 , 5} \mathbf{~ m i}$ & $\mathbf{9 5 6} \mathbf{~ m i l}$ \\
\hline $\mathbf{2 0 1 0}$ & 2011 & 2012 & 2013 & 2014 & 2015 & 2016 & 2017 & 2018 \\
\hline
\end{tabular}

Fonte: INCRA

\section{CONSIDERAÇÕES}

A ocupação da terra pelos quilombolas não é feita em termos de lotes individuais, tal como usualmente. O Instituto Nacional de Colonização e Reforma Agrária (INCRA) operacionaliza lotes para os sem terra. Nas terras quilombolas predomina seu uso comum. De acordo com Haesbaert (2004, p.64), "nas terras quilombolas predomina seu uso comum, e a utilização dessas áreas obedece a critérios de prática de atividades sejam agrícolas, extrativistas ou outras". Observa se, assim, a diferença entre a certificação de um território quilombola e reforma agrária. Assim, a titulação das terras quilombolas é mais do que um bem econômico, transcende para a figura da identidade destas comunidades. Os Gráficos, apenas apresentam os números de comunidades que foram certificadas pela Fundação Palmares, estas comunidades deram o primeiro passo para a obtenção da titulação de suas terras. Sem o 
reconhecimento, as políticas públicas quilombolas não chegam aos quilombos. Mesmo com todos os esforços para a manutenção e preservação da memoria afro brasileira, apenas $6 \%$ dos territórios quilombolas possuem o título da área - na maior parte dos casos, apenas parte dos territórios foram titulados. Conforme os dados levantados na Fundação Palmares, publicados na portaria nํ34/2019, no Brasil há 3.271 comunidades quilombolas certificadas. Apesar dos recursos de 54,2 milhões em 2010 e 50 milhões em 2012 apenas 174 comunidades foram receberam seus títulos de suas terras. Os dados obtidos mostram que o número crescente de comunidades certificadas não é contemplado com os repasses de recursos para titular as terras. Os repasses do governo federal, o processo de certificação das comunidades, as políticas públicas e a presunção da obtenção de títulos estão em direções opostas.

\section{REFERÊNCIAS}

BRASIL. Ministério do Império. Ministro Carlos Leôncio de Carvalho. Relatório do ano 1877 apresentado à Assembleia Geral Legislativa na 1로 Sessão da 17른 Legislatura. Rio de Janeiro: Typ. Nacional, 1878.

BRASIL. Constituição da República Federativa do Brasil: promulgada em 5 de outubro de 1988.

BRASIL. II Plano Nacional de Reforma Agrária: Paz, Produção e qualidade de Vida no Meio Rural. Brasília: 2004. Disponível em: http://sistemas.mda.gov.br/arquivos/PNRA_2004.pdf. Acesso em 10/04/2019

BRASIL. Proposta para desenvolvimento sustentável dos assentamentos rurais. 2003. Disponível em: www.mda.gov.br . Acesso em 12/04/2019

BRASIL, Decreto № 6.261. Dispõe sobre a gestão integrada para o desenvolvimento da Agenda Social Quilombola no âmbito do Programa Brasil Quilombola, e dá outras providências. Disponível em: 
http://www.planalto.gov.br/ccivil_03/_ato2007-2010/2007/decreto/d6261.htm acesso em 26 de março de 2019.

BRASIL. Agricultura Familiar Reforma Agrária e Desenvolvimento Local para um Novo Mundo Rural. Política de Desenvolvimento Rural com Base na Expansão da Agricultura Familiar e sua Inserção no Mercado. Disponível em http://www.nead.org.br. Acesso em 12/04/2019.

BRASIL. Decreto no 4.887, de 20 de novembro de 2003. Diário Oficial da República Federativa do Brasil, Brasília, DF, 20 de novembro de 2003.

BRASIL. Diário Oficial da União. Portaria № 430, Publicado em: 18/02/2019 | Edição: 34 | Seção: 1 | Página: 11.Órgão: Ministério do Desenvolvimento Regional/Secretaria Nacional de Proteção e Defesa Civil. Disponível em: http://www.in.gov.br/materia/-/asset_publisher/Kujrw0TZC2Mb/content/id/63797187 acesso em 27 de abril de 2019.

HAESBAERT, R. Desterritorialização e identidade: a rede "gaúcha" no Nordeste. Niterói: UFF, 1997.

INCRA. Instituto Nacional de Colonização e reforma agrária. Quadro geral de processo de comunidade quilombolas no Brasil. Disponível em: http://www.incra.gov.br/sites/default/files/incraandamentoprocessos acesso em 03/04/2019.

MUNANGA, Kabengele \& GOMES Nilma Lino. O negro no Brasil de hoje. Coleção para entender, São Paulo: Global, 2006.

PIERIN, Gabriel Davi. Movimentos Sociais : os quilombos em movimento. Disponível em: www.cartamaior.com.br/?/Editoria/Movimentos-Sociais/Quilombolas-enfrentamainda-mais-dificuldades-com-os-cortes-orcamentarios/2/34596 em 26 de março de 2019. 
MARTINS, Gabriel. Quilombolas enfrentam dificuldades de acessar serviços públicos. http://g1.globo.com/to/tocantins/noticia/2013/08/quilombolas-enfrentamdificuldades-de-acessar-servicos-publicos.html acesso em 26 de março de 2019.

SILVA. Quilombolas: Resistências, história e cultura. 1ำ edição-São Paulo. Editora IBEP. 2012.

Enviado: Junho, 2019.

Aprovado: Julho, 2019. 